\title{
Geology, mineralogy and mineral chemistry of the NYF-type pegmatites at the Gabal El Faliq area, South Eastern Desert, Egypt
}

\author{
Soliman Abu Elatta Abdallah Mahmoudø \\ Nuclear Materials Authority, Cairo, Egypt. \\ e-mail:dr.Soliman72@yahoo.com
}

MS received 12 September 2018; revised 8 January 2019; accepted 23 January 2019; published online 4 June 2019

The Gabal El Faliq area is located in the Eastern Desert of Egypt and belongs to the Wadi Hafafit-Wadi Ghadir fold belt. Lenses and dykes of rare metal-bearing pegmatites occur along major weak zones in the area (Wadi El Gemal strike-slip and its Riedel shears), by which they are structurally controlled. These pegmatites are mineralogically complex. Moreover, they are zoned, and the intermediate zones of the pegmatite varieties contain high amounts of zircon, fergusonite-(Y), columbite-(Fe), allanite- $(\mathrm{Ce})$, xenotime-(Y), monazite-(Ce and $\mathrm{Nd})$, thorite and gummite. These minerals carry Zr, rare earth element (REE), Nb, Ta, Th, U > Ta, F, and they are classified into rare-metal pegmatites, specifically, the niobium, yttrium and fluorine (NYF) enrichment family. The geochemistry aspects of these pegmatites indicate Zr up to 28,984 ppm, Hf up to $1171 \mathrm{ppm}$, REE up to 19,206 ppm, Nb up to $9962 \mathrm{ppm}$, Ta up to $152 \mathrm{ppm}$, U up to $565.5 \mathrm{ppm}$, Th up to $850 \mathrm{ppm}$ and Ga up to $90 \mathrm{ppm}$. They were formed under an intracontinental tectonic setting from a basaltic magma similar to the oceanic island basalts (OIBs) contaminated with the crust. Consequently, this study could be used as a guide for the exploration of rare metals in similar regions of the world.

Keywords. Gabal El Faliq; Wadi Hafafit-Wadi Ghadir fold belt; Pan-African orogeny; rare-metal NYF pegmatites.

\section{Introduction}

Pegmatite is a term used to describe very coarse (crystals that are at least $1 \mathrm{~cm}$ in diameter) intrusive igneous rocks, which are mafic-syeniticgranitic in composition.

Granitic pegmatites have been classified by Cerný (1991) according to their composition into four classes or categories. This classification is a combination of depth of emplacement, metamorphic grade and minor elements. The classes are abyssal (high-grade metamorphism, high to low pressure), muscovite (high pressure, lower temperature), rare-element (low temperature and pressure) and miarolitic (shallow level). Moreover, rare-element pegmatites are subdivided into lithium, caesium and tantalum (LCT) and niobium, yttrium and fluorine (NYF) families. The LCT family is characterised by $\mathrm{Li}, \mathrm{Rb}, \mathrm{Cs}, \mathrm{Be}, \mathrm{Ga}$, $\mathrm{Sn}, \mathrm{Hf}, \mathrm{Nb}<>\mathrm{Ta}, \mathrm{B}, \mathrm{P}, \mathrm{F}$, and the NYF family is characterised by $\mathrm{Y}$, rare earth element (REE), Ti, U, Th, Zr, Nb > Ta, F (Černý 1991). Consequently, some pegmatite types are a source of REEs and gemstones. 
Rare metal (Nb, Ta, U, Th, Zr and REE) deposits were discovered in felsic igneous rocks from Egypt, including alkaline/peralkaline igneous rocks and hydrothermally altered parts of them (e.g., Abu Elatta 2018), apogranites and pegmatites. The alkaline/peralkaline rocks in Egypt were formed during the period between the late Pan-African orogeny ( $\sim 600 \mathrm{Ma})$ to post-Cretaceous (50 Ma, Vail 1989) along the continental breakup by the major shear zones (e.g., Garson and Kris 1976; Hashad and El Reedy 1979; Serencits et al. 1979; Abu Elatta et al. 2013; El Sayed et al. 2014). Apogranite is a specialised granitic type (albitised granite) having rare metals (Sabet and Tsogoev 1973; Beus 1982), and was studied by, e.g., Omar (1995), Attawiya et al. (2000), Raslan (2008) and Ali et al. (2011). Rare metal-bearing pegmatites were recorded in many localities in Egypt (figure 1), especially in the Eastern Desert, and they are of LCT or NYF families. For example, pegmatites of the LCT family occur at Abu Rusheid (Sabet and Tsogoev 1973), and pegmatites of the NYF family occur at Ras Baroud (Omar 1995) and Kadabora (El-Sayed 2003).

This paper presents the geology of the pegmatites that cross-cut the Gabal El Faliq leucogranites and their tectonic relation with the Wadi Hafafit-Wadi Ghadir rock units. The mineralogical, mineral chemistry and geochemical studies of the intermediate zones of the pegmatites show mineralisation with $\mathrm{Zr}$, Hf, REE, Nb, Ta, U, Th and Ga. This work was to understand if these pegmatites were formed by the in-situ partial melting or by the fractionation from mantle-derived magma.

\section{Geological setting}

\subsection{Regional geology}

The late Pan-African Gabal El Faliq leucogranites occur along the south-western side of the Wadi Hafafit-Wadi Ghadir area, in the South Eastern Desert of Egypt (figure 2a). The Wadi HafafitWadi Ghadir area is part of the Arabian-Nubian shield of the Eastern Desert of Egypt and consists of two major groups, which are separated by the Nugrus thrust. The structurally lower group in the foot wall of this thrust is characterised by the Migif-Hafafit gneisses and associated rocks which have been affected by medium-grade metamorphism, whereas the structurally upper group or hanging wall is characterised by the Wadi Ghadir mélange which has experienced low-grade metamorphism (El-Ramly et al. 1993). These groups were formed as a result of the Pan-African convergent and marginal ocean basin processes. In addition to these, there are a group of Phanerozoic

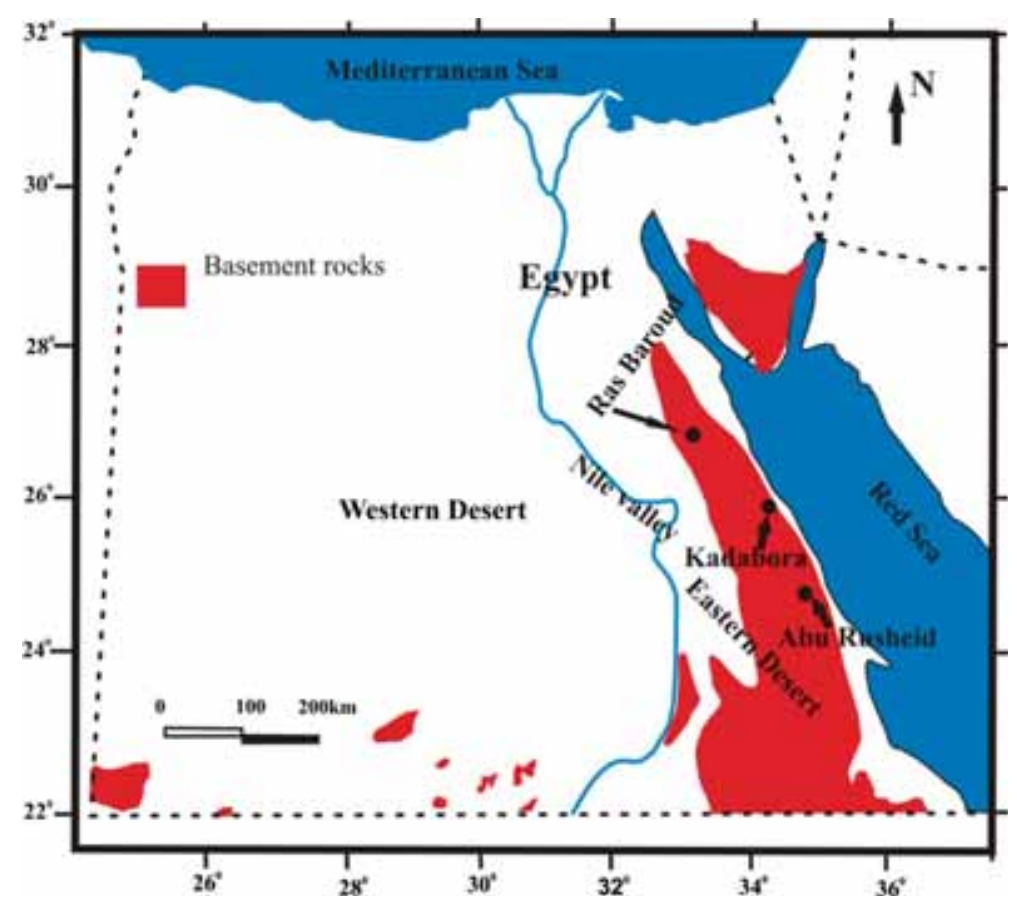

Figure 1. Locations of some rare-metal pegmatites in the Eastern Desert of Egypt. 

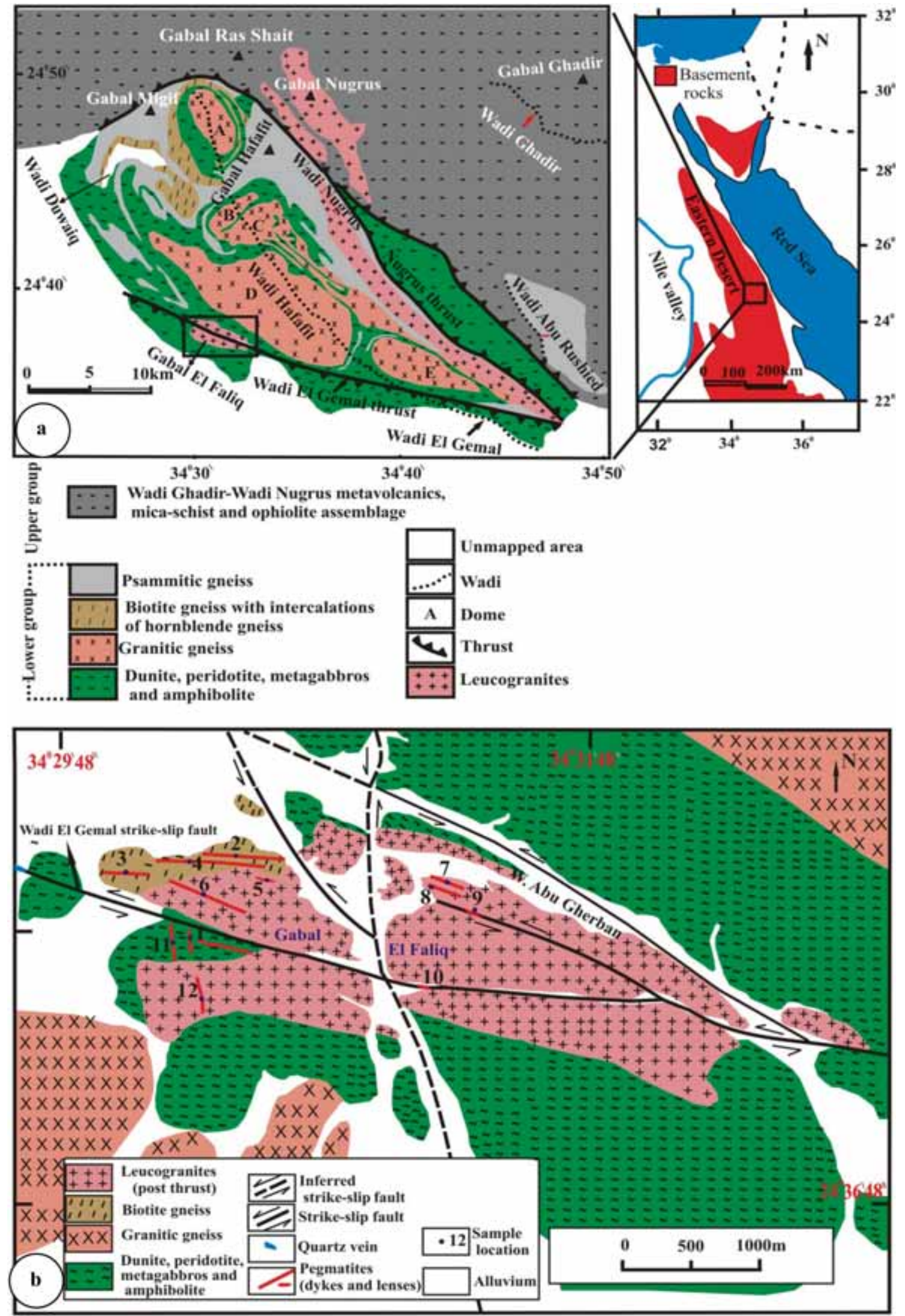

Figure 2. (a) Geologic map of the Hafafit area (El-Ramly et al. 1993; Abd El-Naby and Frisch 2006) and (b) detailed geologic map of Gabal El Faliq (modified from El-Ramly et al. 1993) showing sample locations in black numbers. 
intrusive (unmappable) and alluvium (El-Ramly et al. 1984).

The Migif-Hafafit gneisses form the Hafafit domes. These comprise the orthogneiss of tonalitic, trondhjemitic and granodioritic composition, banded amphibolites overthrusted by ultramafic rocks, alternating bands of biotite and hornblende and psammitic gneisses. In some parts, the amphibolite is associated with metagabbros, while the upper group, the Wadi Ghadir mélange forming the Ghadir ophiolite includes mica-schists and metavolcanics (Abd El-Naby and Frisch 2006).

The sequence of rock units in the Wadi HafafitWadi Ghadir fold belt was formed as follows: Firstly, the ophiolites of the Arabian Nubian shield (including the Hafafit-Ghadir area) by the rifting of Rodinia (Abdelsalam and Stern 1996) between 900 and $740 \mathrm{Ma}$ (Ries et al. 1983; Kroner et al. 1994; Loizenbauer et al. 2001). The event was followed by the development of sutures associated with the arc accretion between 750 and $650 \mathrm{Ma}$ (Abdelsalam and Stern 1996; Blasband et al. 2000), when the tonalitic, trondhjemitic and granodioritic granites at the core of the Hafafit domes were formed as a result of the convergence and associated orogen-parallel extension (figure 3a). Secondly, the late- to post-tectonic magmatic activity (Stern and Hedge 1985; Hassan and Hashad 1990) and molasse basin formation (Grothaus et al. 1979; Willis et al. 1988; Rice et al. 1993) occurred between 620 and $580 \mathrm{Ma}$ (Fritz et al. 2002) as a result of the arc-continent or arc-arc collision. This event is responsible for overthrusts taking place in the Hafafit-Ghadir area, where the Ghadir ophiolite mélange was thrust over the Hafafit units and led to a medium grade of amphibolite facies regional metamorphism that caused the orthogneisses (previously tonalitic, trondhjemitic and granodioritic granites) in the Hafafit units. In addition, this event increased the crustal thickening and caused a widespread partial-melting along the thrust zones, where leucogranites in the Hafafit area (including the Gabal El Faliq granites; figure $3 \mathrm{~b}$ ) were emplaced along the thrusts around $600 \mathrm{Ma}$ (Abd El-Naby and Frisch 2006). This stage of crustal thickening and the emplacement of the leucogranites were accompanied by active strike-slip faults or shear zones, especially along the previous crustal weaknesses (Moghazi et al. 2004). These strike-slip faults or shear zones were deeper, so that, they were associated with magmas that have been represented by pegmatite dykes and lenses in the study area within the fault zones and related Riedel shears (figure 3c). In addition, these faults or shear zones may have been reactivated during the Red Sea opening or before, as explained by the cracks in the pegmatites.

\subsection{Gabal El Faliq leucogranites}

The Gabal El Faliq leucogranitic rocks occur as an elongated body along the NW-SE oriented Wadi El Gemal thrust and cover an area of about $5.65 \times 1.67 \mathrm{~km}$ (figure $2 \mathrm{~b}$ ), forming a moderate relief terrain with the Gabal El Faliq peak of $664 \mathrm{~m}$ above sea level. The leucogranites intruded into the Wadi Hafafit rock units and are dissected by a major sinistral strikeslip fault (the Wadi El Gemal strike-slip fault) and associated Riedel shears. The main strike of this fault is the NW-SE trend, whereas the trends of synthetic Riedel shear strikes are E$\mathrm{W}$ and N-S trends, respectively. The zones of these faults vary in width and are characterised by fault breccias, gouge, ferrugination (figure 4a) and pegmatite bodies that have abnormal concentrations of rare metals, such as $\mathrm{Nb}, \mathrm{Ta}, \mathrm{Th}$, $\mathrm{U}, \mathrm{Zr}, \mathrm{HF}$ and REE in a few parts, while the other parts are covered by the Wadi sediments. The leucogranitic rocks contain many large xenoliths from the country rocks along their margins (figure 4b). Additionally, some basic dykes with a NW-SE trend also have been intruding into these leucogranites.

Saleh et al. (2014) divided the Gabal El Faliq leucogranites into two varieties according to their mineral contents: the first is represented by monzogranite and the second, by alkali feldspar (AF) granite.

\subsection{Pegmatites}

The granitic pegmatites at the Gabal El Faliq area occur as dykes and lenses. Granitic pegmatitic dykes cut all the rock units in the Gabal El Faliq area (figure 4c), where there is no relationship among them in the studied area. These pegmatites intrude into the Wadi El Gemal fault and the related Riedel shears, so that they are coincident with the NW-SE, E-W, and N-S strikes of these faults. Their widths range from $0.20 \mathrm{~cm}$ to $2 \mathrm{~m}$ and the lengths vary. They have sharp contacts with the host rocks (figure 4d). They are zoned (figure $4 \mathrm{~d}$ 

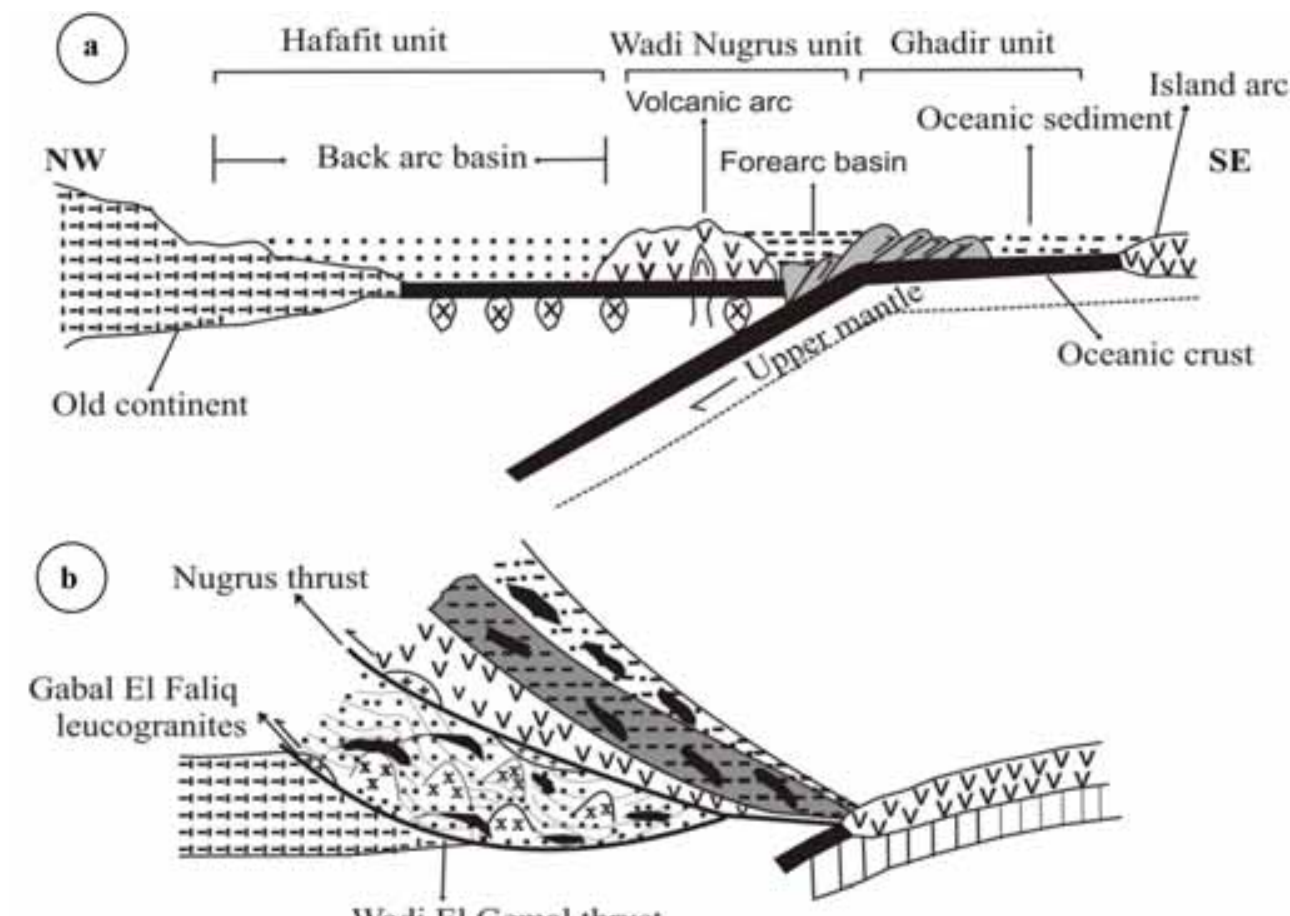

Wadi El Gemal thrust

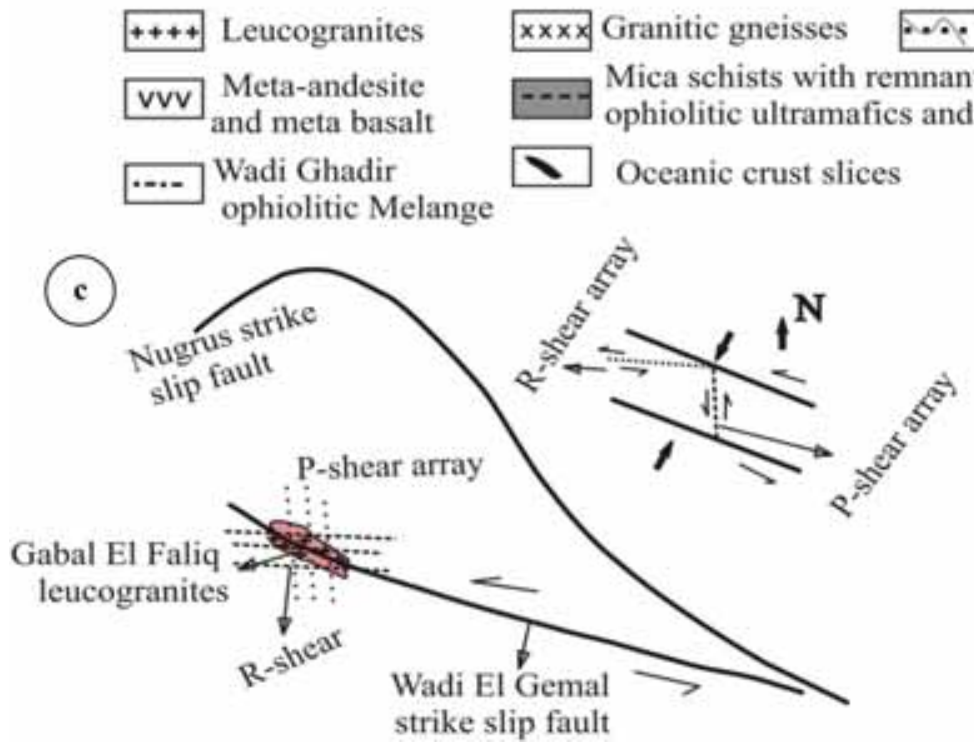

Figure 3. Plate-tectonic model for the evolution of the Wadi Hafafit-Wadi Ghadir rock units; where (a) and (b) are sketch diagrams (after Abd El-Naby and Frisch 2006) illustrating the development of the Gabal El Faliq leucogranites and their tectonic relation with the Wadi Hafafit-Wadi Ghadir rock units; (a) >650 Ma: subduction of the oceanic crust, ophiolite detachment and thrusting with arc volcanism, arc-related plutonism and back-arc basin development in the Hafafit-Ghadir region, (b) $600 \mathrm{Ma}$ : collision and thrusting of the Nugrus unit over the Hafafit unit, leucogranite intrusion along thrust zones and regional metamorphism and (c) is sketch diagram showing trends of the Wadi El Gemal strike-slip fault and it Riedel shears where the pegmatites were injected.

and e) and are divided into complex-type granitic pegmatites. The pegmatites show complex mineralogy and textures, where their mineral composition and texture vary from the wall zones to the core zones. Additionally, they contain xenoliths from host rocks, and especially those found on the northwestern side of Gabal El Faliq (figure 4e). The intermediate zones of these pegmatites have high concentrations of rare metal-bearing pegmatites (figure $4 \mathrm{f}-\mathrm{h}$ ). Pegmatite lenses up to $30 \mathrm{~m}$ in length and $10 \mathrm{~m}$ in width occur along the NW-SE sinistral strike-slip fault and its related shears. Furthermore, they are of the zoned complex type with the same mineral composition of pegmatitic dykes. 

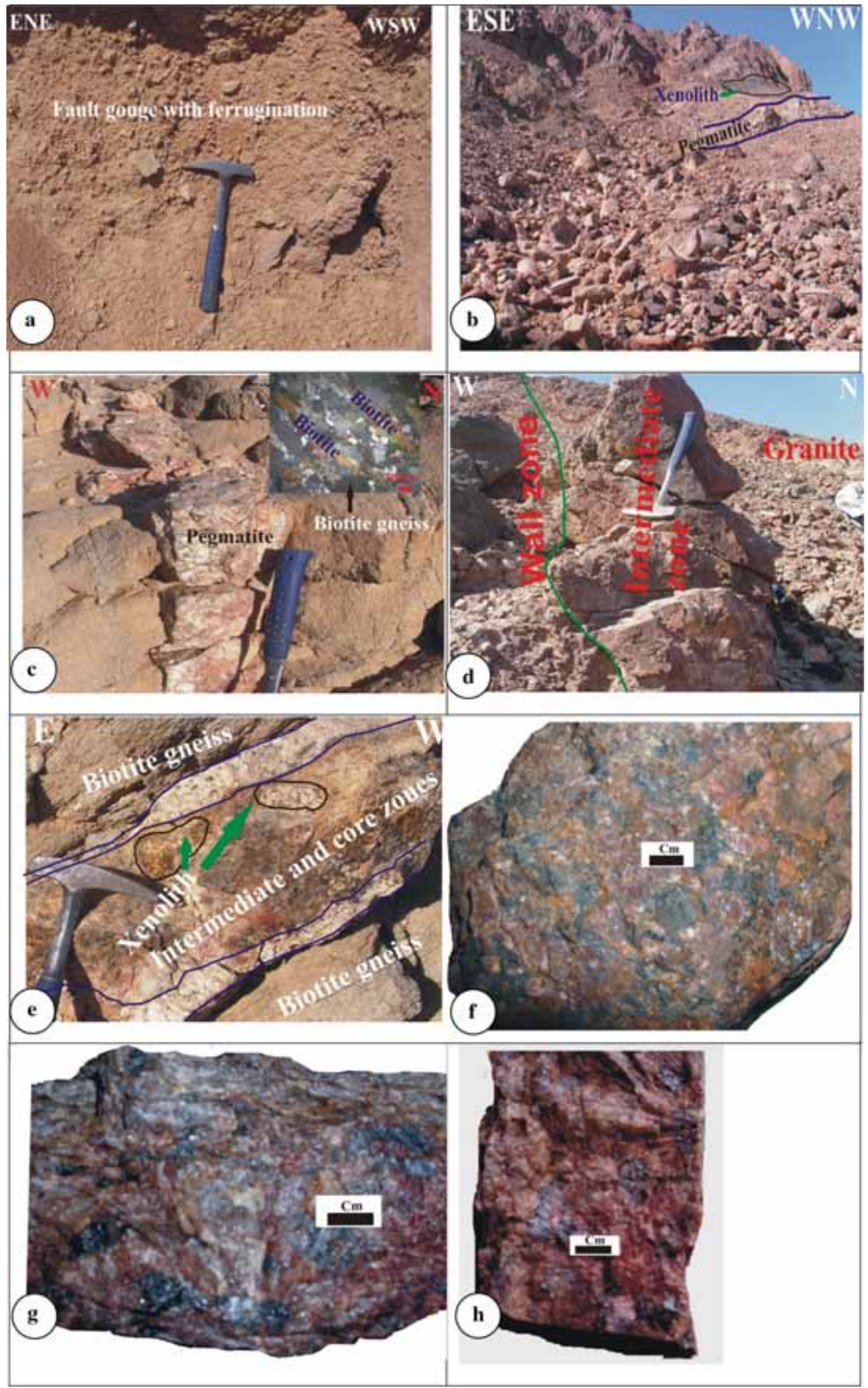

Figure 4. (a-e) are field photographs showing, ferrugination and fault gouge, a large xenolith from the older mafic rocks in leucogranites, a sharp contact between a pegmatitic dyke and the host rock and zoned pegmatites, respectively, whereas $(\mathbf{f}-\mathbf{h})$ are photographs of samples from pegmatite intermediate zones that contain high concentrations of rare metal-bearing minerals. 


\section{Methodology}

The locations of all samples collected from the pegmatites are shown in figure 2(b). A total number of 17 thin sections ( 5 from country rocks and 12 from pegmatite intermediate zones) were studied petrographically by using an optical microscope and a scanning electron microscope attached to a JEOL JXA-8900L electron microprobe equipped with a $\mathrm{Si}(\mathrm{Li})$ energy dispersive spectrometer (EDS) and five wavelength dispersive spectrometer (WDS, Department of Earth and Planetary Sciences, McGill University). Most of the minerals except main rock-forming minerals were identified from compositional data using EDS. Quantitative analyses were conducted in the WDS mode with a beam current of $50 \mathrm{nA}$, an acceleration voltage of $20 \mathrm{kV}$ and a dwell time of $60 \mathrm{~ms}$. An environmental scanning electron microscope (ESEM) coupled with an energy dispersive X-ray spectroscope (EDX) (Laboratory of Nuclear Materials Authority, Egypt) was also used to identify some minerals. Separated heavy minerals were hand-picked under the microscope and analysed by ESEM/EDX. Acme Labs., Canada using ICP-OES and ICP-MS methods to analyse eight representative samples from the pegmatite intermediate zones for whole-rock compositions (two samples of Nos. 2 and 10 from lenses and the other six samples from dykes) (table 1).

\section{Results}

\subsection{Mineralogy}

\subsubsection{Leucogranites mineralogy}

The two types of leucogranites are highly sheared by faults, and all crystals are deformed and cracked (figure 5a). The monzogranite is pink in colour and is composed essentially of $\mathrm{K}$-feldspars, sodic plagioclase and biotite with a minor amount of muscovite and hornblende. The accessory minerals are titanite, zircon, garnet and opaque minerals (figure 5b). K-feldspars are orthoclase perthite dominant and also contain microcline perthite. Two types of quartz were found, particularly, the samples were taken from the fault zones: the first one occurs as subhedral to anhedral crystals showing undulatory extinction. It causes corrosion of feldspar minerals, and the second is smaller, relative to the first one. It is squeezed among the primary minerals (figure 5c) and fractured crystals. AF granite is brick-red in colour, medium- to coarse-grained and mainly consists of K-feldspars, quartz and albite, with minor traces of alkali amphibole (arfvedsonite). Anhedral opaque crystals, zircon and monazite are the accessory minerals. K-feldspars are represented by predominantly string (figure 5d) and patchy types of microcline perthite more than orthoclase perthite.

\subsubsection{Pegmatites mineralogy}

The intermediate zones of the pegmatite dykes and lenses were studied in detail because they contain a large amount of rare metal-bearing minerals. The intermediate zones are composed essentially of quartz (53-80\% by volume), magnetite and titanomagnetite (5-25\% by volume), patch perthite (3-17.5\% by volume), with a minor amount of arfvedsonite (about $0.5 \%$ by volume) and haematite ( $3 \%$ by volume). Chlorite and biotite are occasionally found in the pegmatite bodies that were intruded into biotite gneisses. The rare metal-bearing minerals are zircon (0.1$5 \%$ by volume), fergusonite-(Y) (0.3-3\% by volume), allanite-(Ce) (1-4\% by volume), monazite(Ce and $\mathrm{Nd}),(0.5 \%$ by volume), with a small amount of columbite-(Fe), xenotime-(Y), thorite and gummite that form about $1 \%$ by volume.

Quartz occurs as colourless crystals that have been deformed and show undulatory extinction. These crystals are accompanied by oriented chlorite (figure 6a) and/or feldspar (patch perthite). These textures suggest that the Gabal El Faliq pegmatites were emplaced into fault zones, where these faults reactivated prior to the complete crystallisation of the pegmatites. Magnetite and titanomagnetite occur as dark anhedral mega crystals (up to $3 \mathrm{~cm}$ in length and $1.5 \mathrm{~cm}$ in width). These crystals are fractured with two or more sets of fractures and contain zircon and fergusonite inclusions (figure 6b). Additionally, fractures are filled with microvienlets of fergusonite (figure 6c) and/or quartz. Zircon occurs as euhedral to subhedral crystals with pyramidal terminations. These crystals vary in size from medium to mega-crystals (up to $2.0 \mathrm{~cm}$ in length and $1.2 \mathrm{~cm}$ in width; figure $6 \mathrm{~d}$ and e) and colours, with colour zoning (figure $5 \mathrm{~d}$ and e). The zircons contain many inclusions of fergusonite (figure 6f), columbite, xenotime and haematite (figure 6g). Allanite-(Ce) shows a shade of brown colour with a dark core in the thin sections (figure 6h) and is pleochroic in brown, red-brown and yellow-brown colours. Most of the allanite crystals were altered and occur in 
Table 1. Whole-rock geochemical data in wt\% (major oxides) and ppm (trace and REEs) of the Gabal El Faliq pegmatite intermediate zones.

\begin{tabular}{|c|c|c|c|c|c|c|c|c|}
\hline Sample/oxide & 2 & 4 & 6 & 7 & 8 & 9 & 10 & 12 \\
\hline $\mathrm{SiO}_{2}$ & 62.75 & 78.41 & 73.73 & 83.99 & 69.83 & 71.41 & 83.01 & 62.16 \\
\hline $\mathrm{TiO}_{2}$ & 0.28 & 0.31 & 0.53 & 0.35 & 0.7 & 0.59 & 0.2 & 0.67 \\
\hline $\mathrm{Al}_{2} \mathrm{O}_{3}$ & 6.89 & 4.25 & 0.86 & 2.73 & 0.80 & 0.92 & 3.76 & 1.12 \\
\hline $\mathrm{Fe}_{2} \mathrm{O}_{3} \mathrm{t}$ & 22.68 & 12.7 & 21.43 & 9.22 & 27.4 & 24.67 & 4.7 & 28.97 \\
\hline $\mathrm{MgO}$ & 0.07 & 0.06 & 0.03 & 0.1 & 0.03 & 0.08 & 0.14 & 0.06 \\
\hline $\mathrm{CaO}$ & 0.76 & 0.51 & 0.13 & 0.61 & 0.05 & 0.08 & 0.39 & 0.23 \\
\hline $\mathrm{Na}_{2} \mathrm{O}$ & 1.16 & 1.63 & 0.06 & 0.88 & 0.02 & 0.1 & 0.12 & 0.7 \\
\hline $\mathrm{K}_{2} \mathrm{O}$ & 3.56 & 0.54 & 0.03 & 0.45 & 0.02 & 0.07 & 0.38 & 0.1 \\
\hline $\mathrm{P}_{2} \mathrm{O}_{5}$ & 0.04 & 0.02 & $<0.01$ & 0.05 & $<0.01$ & $<0.01$ & 0.16 & $<0.01$ \\
\hline $\mathrm{MnO}$ & 0.06 & 0.12 & 0.07 & 0.07 & 0.08 & 0.13 & 0.02 & 0.14 \\
\hline L.O.I & 0.5 & 0 & 0.5 & 0.8 & 0.5 & 0.7 & 2.1 & 1.2 \\
\hline Total & 98.75 & 98.55 & 97.37 & 99.25 & 99.43 & 98.75 & 94.98 & 95.35 \\
\hline \multicolumn{9}{|l|}{ Trace elements } \\
\hline $\mathrm{Ba}$ & 352 & 74 & 9 & 118 & 5 & 27 & 108 & 13 \\
\hline Cs & 0.2 & 0.1 & $<0.1$ & 0.2 & $<0.1$ & $<0.1$ & 0.3 & 0.1 \\
\hline $\mathrm{Ga}$ & 31.7 & 20.4 & 68.6 & 16 & 89.8 & 59.8 & 10 & 53.3 \\
\hline Hf & 65.3 & 25.4 & 211.8 & 18 & 46.6 & 36.3 & 1170.9 & 384.8 \\
\hline $\mathrm{Rb}$ & 59.2 & 8.6 & 2 & 6.8 & 0.8 & 1.7 & 8.7 & 4.6 \\
\hline $\mathrm{Sr}$ & 114 & 40 & 10.6 & 60 & 3.3 & 9.9 & 52 & 21.6 \\
\hline $\mathrm{Nb}$ & 2911.4 & 4285 & 4795.6 & 2108 & 915 & 3066.4 & 1914.8 & 9661.8 \\
\hline $\mathrm{Zn}$ & 124 & 166 & 430 & 132 & 428 & 185 & 153 & 588 \\
\hline $\mathrm{Ta}$ & 43.2 & 140.8 & 152.4 & 25.5 & 85 & 65.3 & 67 & 146.5 \\
\hline $\mathrm{Zr}$ & 1695.2 & 579 & 4151.3 & 443.6 & 656.4 & 877.3 & $28,983.8$ & 8964 \\
\hline $\mathrm{U}$ & 123.4 & 184.9 & 332.3 & 87.1 & 90.3 & 192 & 240.4 & 565.5 \\
\hline Th & 220.1 & 301.3 & 850 & 174.5 & 597 & 257.7 & 195.9 & 881.5 \\
\hline \multicolumn{9}{|l|}{$R E E$} \\
\hline $\mathrm{La}$ & 51.5 & 21.8 & 343.5 & 11.2 & 7.5 & 90.4 & 291 & 990.2 \\
\hline $\mathrm{Ce}$ & 173.6 & 92.3 & 1121.8 & 34.7 & 31.8 & 316.4 & 745.3 & 3113.3 \\
\hline $\mathrm{Pr}$ & 32.11 & 22.55 & 157.78 & 8.12 & 6.7 & 45.18 & 107 & 450.93 \\
\hline $\mathrm{Nd}$ & 189.6 & 166.6 & 732.3 & 69.9 & 44.7 & 236.6 & 487.9 & 2012.2 \\
\hline $\mathrm{Sm}$ & 123.99 & 144.89 & 289.48 & 69.13 & 36.79 & 125.91 & 172.8 & 688.2 \\
\hline $\mathrm{Eu}$ & 6.43 & 8.18 & 5.84 & 3.77 & 0.33 & 5.52 & 6.46 & 13.56 \\
\hline Gd & 227.11 & 297.94 & 472.87 & 164.94 & 68.73 & 245.4 & 233.75 & 1028 \\
\hline $\mathrm{Tb}$ & 55.34 & 75.48 & 109.2 & 40.75 & 16.56 & 60.11 & 54 & 229.7 \\
\hline Dy & 381.8 & 551.48 & 748.25 & 290.17 & 110.5 & 433.5 & 395.27 & 1609.15 \\
\hline Но & 80.5 & 118.4 & 166.35 & 61.69 & 24.17 & 99 & 90.32 & 350.52 \\
\hline Er & 228 & 347.17 & 454.79 & 171.17 & 71.5 & 292.18 & 288.5 & 973.52 \\
\hline $\mathrm{Tm}$ & 30.37 & 50.16 & 63.68 & 22.23 & 11 & 41 & 47.96 & 126.52 \\
\hline $\mathrm{Yb}$ & 156.79 & 286.32 & 341.84 & 114.19 & 70.84 & 228.77 & 301.39 & 664.83 \\
\hline $\mathrm{Lu}$ & 18.72 & 37.19 & 41.21 & 13.24 & 9.5 & 28.21 & 43.45 & 76.95 \\
\hline $\mathrm{Y}$ & 1703.8 & 2914.7 & 3427 & 1378.2 & 565.9 & 199.4 & 2182 & 6878.2 \\
\hline$\sum \mathrm{LREE}$ & 577.23 & 456.32 & 2650.7 & 196.82 & 127.82 & 820.01 & 1810.46 & 7268.39 \\
\hline$\sum \mathrm{HREE}$ & 2882.43 & 4678.84 & 5825.19 & 2256.58 & 948.7 & 1627.25 & 3636.64 & $11,937.39$ \\
\hline$\sum \mathrm{REE}$ & 3459.66 & 5135.16 & 8475.89 & 2453.4 & $10,767.52$ & 2447.58 & 5447.1 & $19,205.78$ \\
\hline $\mathrm{Eu} / \mathrm{Eu}^{*}$ & 0.12 & 0.12 & 0.05 & 0.11 & 0.02 & 0.1 & 0.1 & 0.05 \\
\hline $\mathrm{Th} / \mathrm{U}$ & 1.78 & 1.63 & 2.58 & 2.00 & 6.61 & 1.34 & 0.81 & 1.59 \\
\hline $\mathrm{Rb} / \mathrm{Cs}$ & 296 & 86 & u.d. & 34 & u.d. & u.d. & 27.7 & 46 \\
\hline $\mathrm{Nb} / \mathrm{Ta}$ & 67.39 & 30.4 & 31.46 & 82.67 & 10.78 & 46.95 & 28.78 & 65.95 \\
\hline $\mathrm{Zr} / \mathrm{Hf}$ & 25.96 & 22.6 & 19.6 & 24.64 & 14.1 & 24.17 & 24.75 & 23.3 \\
\hline $\mathrm{Y} / \mathrm{Nb}$ & 0.59 & 0.68 & 0.71 & 0.65 & 0.62 & 0.07 & 1.14 & 0.71 \\
\hline
\end{tabular}

$\mathrm{Fe}_{2} \mathrm{O}_{3} \mathrm{t}=$ total iron, HREEs include $\mathrm{Y}$, u.d. = under detection limit. 

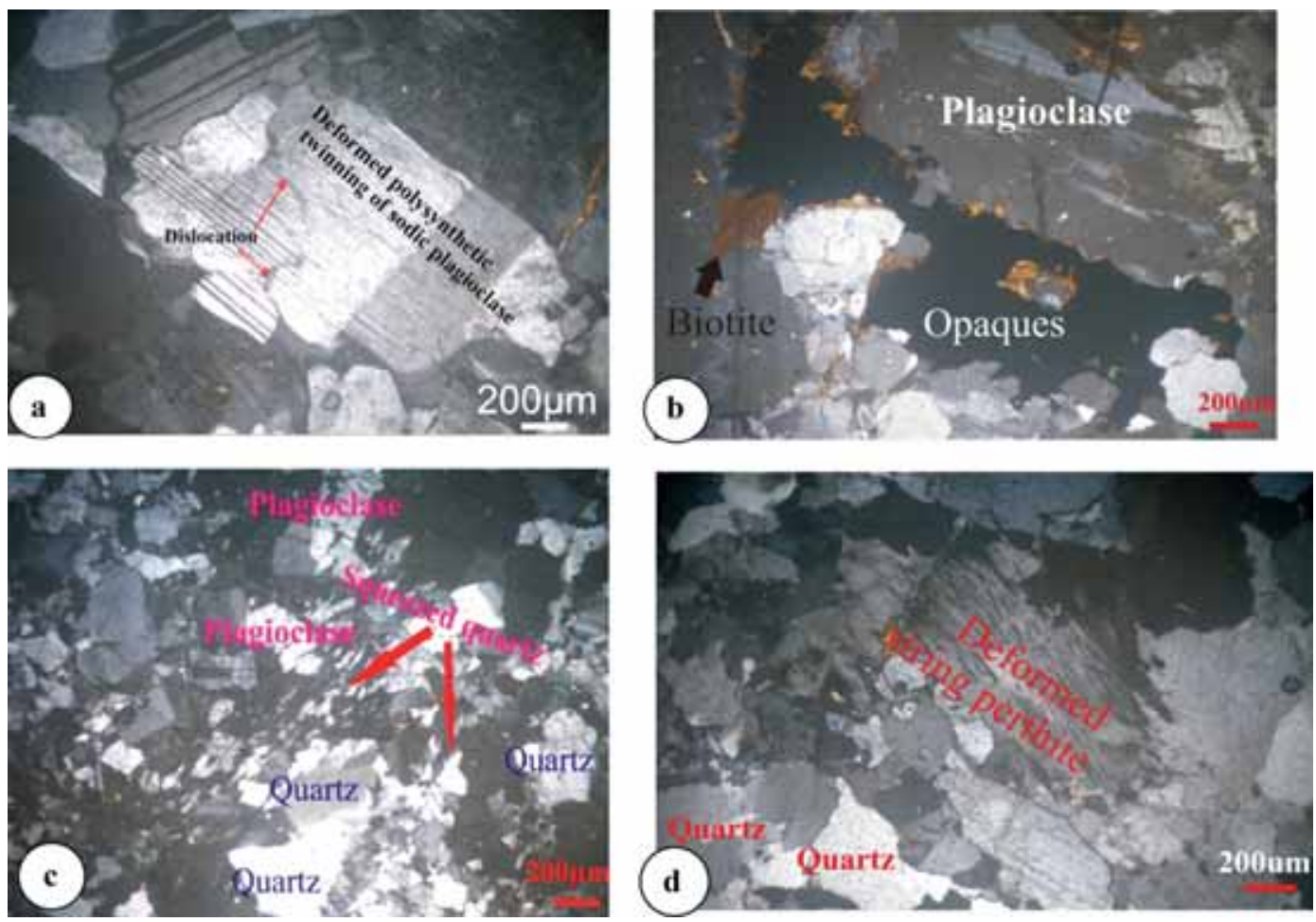

Figure 5. Optical microphotographs (CN) showing (a) deformed polysynthetic twinning of plagioclase, (b) opaque minerals, (c) squeezed quartz, and (e) deformed string perthite ( $\mathrm{CN}=$ Crossed Nicols).

different sizes from medium to mega-crystals (up to $1.6 \mathrm{~cm}$ in length and $0.5 \mathrm{~cm}$ in width; figure $6 \mathrm{~h}-\mathrm{j})$. These crystals contain inclusions of monazite-(Ce) (figure $6 \mathrm{i}$ and $\mathrm{j}$ ). Fergusonite-(Y) occurs as reddishbrown euhedrals to subhedral prismatic crystals and the aggregates vary in size from medium to mega-crystals (up to $2.4 \mathrm{~cm}$ in length and $0.6 \mathrm{~cm}$ in width; figure $6 \mathrm{k}$ and 1 ). Columbite crystals are locally found as large black prismatic crystals but they commonly exist as inclusions in zircon as mentioned above. Xenotime occurs as euhedral to subhedral prismatic grey colour crystals, commonly fractured (figure $6 \mathrm{~m}$ and $\mathrm{n}$ ). These crystals are also found as inclusions in thorite and zircon crystals (figure $6 \mathrm{~d}$ and $\mathrm{g}$ ). Monazite occurs as minor reddish-brown monazite-(Ce) crystals (figure $6 \mathrm{i}$ ) and monazite-(Nd) which is more abundant either in the form of large or small pale yellow prismatic crystals (figure 6o). Thorite occurs as anhedral black or brown prismatic crystals. Gummite occurs as yellow-coloured grains (figure $6 \mathrm{p}$ ) and may be formed as a result of uraninite alteration.

\subsection{Pegmatites mineral chemistry}

Quantitative electron microprobe analyses were carried out on fergusonite [(Y,REE) $\left.\mathrm{NbO}_{4}\right]$, allanite $\quad\left[(\mathrm{Ce}, \mathrm{Ca}, \mathrm{Y}, \mathrm{La})_{2}\left(\mathrm{Al}, \mathrm{Fe}^{3+}\right)_{3}\left(\mathrm{SiO}_{4}\right)_{3}(\mathrm{OH})\right]$ and zircon $\left(\mathrm{ZrSiO}_{4}\right)$, and semi-quantitative analyses by ESEM/EDX for titanomagnetite $\left[\mathrm{Fe}^{2+}\left(\mathrm{Fe}^{3+}\right.\right.$, $\left.\mathrm{Ti})_{2} \mathrm{O}_{4}\right]$, xenotime $\left(\mathrm{YPO}_{4}\right)$, monazite $(\mathrm{Nd}, \mathrm{Ce}$, $\mathrm{La}, \mathrm{Th})(\mathrm{P}, \mathrm{Si}) \mathrm{O}_{4}$, thorite $\left(\mathrm{ThSiO}_{4}\right)$ and gummite $\left(\mathrm{U}_{3} \mathrm{O}_{8}\right)$.

The electron microprobe analyses of fergusonite crystals (15 crystals; table 2 ) reveal that they contain $\mathrm{Nb}_{2} \mathrm{O}_{5}$ (46.72-50.03 wt\%), followed by $\mathrm{Y}_{2} \mathrm{O}_{3}$ (27.29-28.84 wt\%), with total heavy rare-earth oxides (HREO) including $\mathrm{Y}_{2} \mathrm{O}_{3}$ (40.38-44.86 wt\%) and total light rare-earth oxides (LREO: 1.73$3.71 \mathrm{wt} \%)$ as well. Furthermore, they contain $\mathrm{UO}_{2}(1.62-2.19 \mathrm{wt} \%)$ with a considerable amount of $\mathrm{ThO}_{2}$ (0.81-2.01 wt\%), and they represent fergusonite-(Y). The chondrite-normalised REE patterns of fergusonite (figure 7) show high heavy rare-earth elements (HREEs) with pronounced negative $\mathrm{Eu}$ anomalies. In addition, some crystals show positive $\mathrm{Ce}$ anomalies and negative $\mathrm{Pr}$ anomalies at the same time.

The electron microprobe analyses of zircon crystals (7 spots: table 3) contain (63.54-64.34 wt\%) $\mathrm{ZrO}_{2}$ and (32.49-33 wt\%) $\quad \mathrm{SiO}_{2}$ with a significant amount of $(2.22-2.29 \mathrm{wt} \%) \mathrm{HfO}_{2}$. These crystals have significant concentrations of rare earth oxides (REO) (0.429-1.245 wt\%), mostly HREO. In addition, they are very rich in $\mathrm{U}$ relative to $\mathrm{Th}$. 

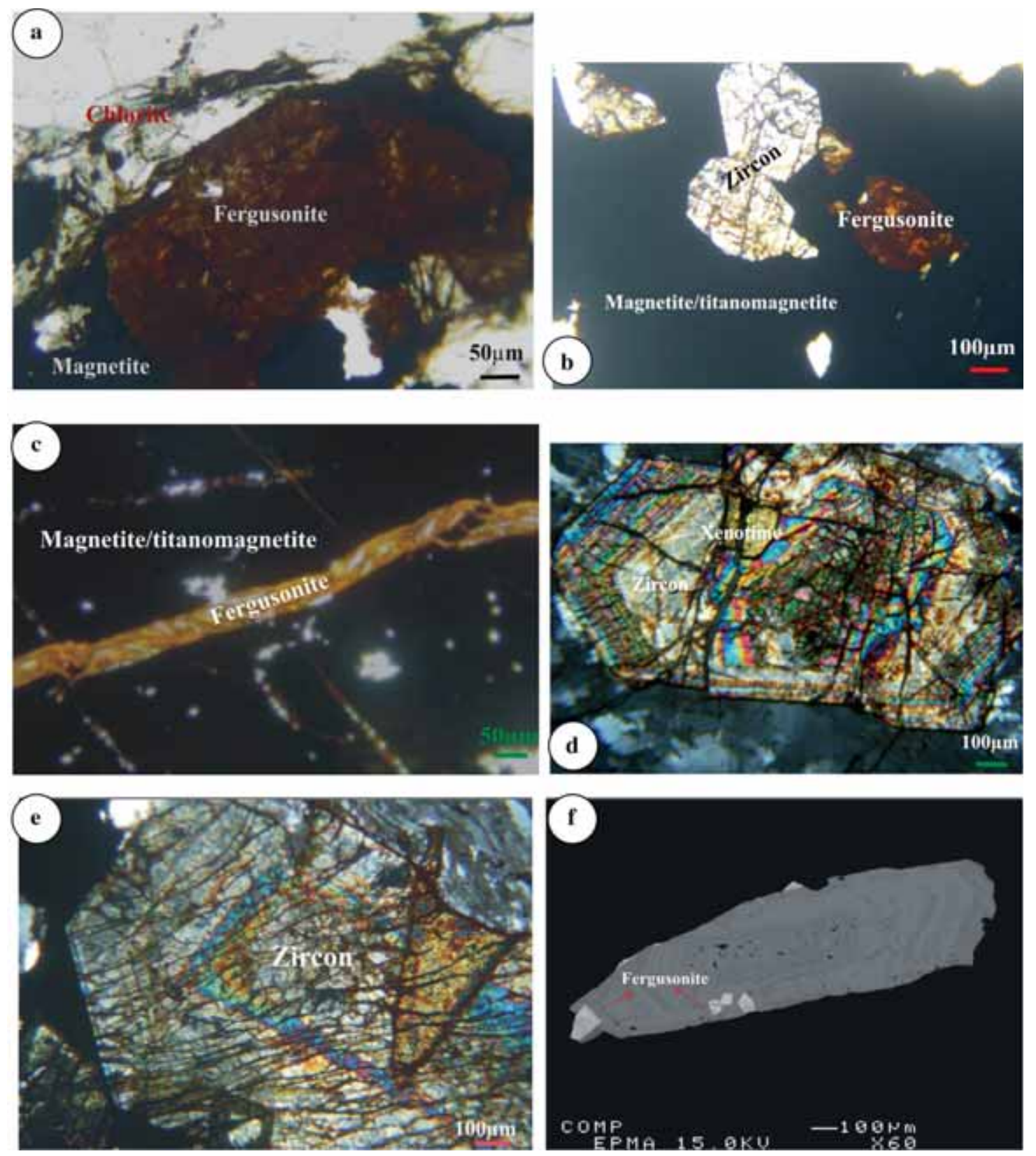

Figure 6. (a-c) Optical microphotographs (normal light (NL)) showing chlorite and fergusonite, magnetite/titanomagnetite contains zircon and fergusonite as inclusions, and a fracture in magnetite/titanomagnetite filled by fergusonite, respectively, ( $\mathbf{d}$ and $\mathbf{e}$ ) are optical microphotographs (CN) showing mega-crystals of zircon containing xenotime as inclusions, (f and $\mathbf{g}$ ) are backscattered electron (BSE) images showing zircon crystals containing inclusion of fergusonite, xenotime and haematite, (h and i) are optical microphotographs showing mega-crystals of allanite with a dark core in $\mathbf{h}$ and contains monazite-(Ce) in (i), and (j) is BSE for allanite containing monazite- $(\mathrm{Ce})$, (k) and (l) are optical microphotographs (NL) showing aggregates of fergusonite mega-crystals, and $(\mathbf{m}-\mathbf{p})$ are BSE images for thorite grain, rock fragment contains cracked xenotime, zircon and fergusonite, minute crystals of monazite-(Nd) and grains of gummite, respectively.

Furthermore, $\mathrm{Fe}_{2} \mathrm{O}_{3} \mathrm{t}$ (total iron as $\mathrm{Fe}_{2} \mathrm{O}_{3}$ ) and $\mathrm{TiO}_{2}$ are very limited. The chondrite-normalised REE patterns of zircon crystals (figure 8) show an enrichment in the HREE relative to the light rare-earth element (LREE). Additionally, Eu is depleted in most crystals. These results indicate that the zircon crystals were formed in an oxygenated environment from hydrothermal solutions which came from highly differentiated magma.

The electron microprobe analyses of allanite crystals (eight crystals; table 4) showed that they contain $\mathrm{SiO}_{2}$ (31.5-34.09 wt\%), followed by REEO $(22.51-24.00 \mathrm{wt} \% ; \mathrm{LREO}=21.05-22.38 \mathrm{wt} \%$ and 

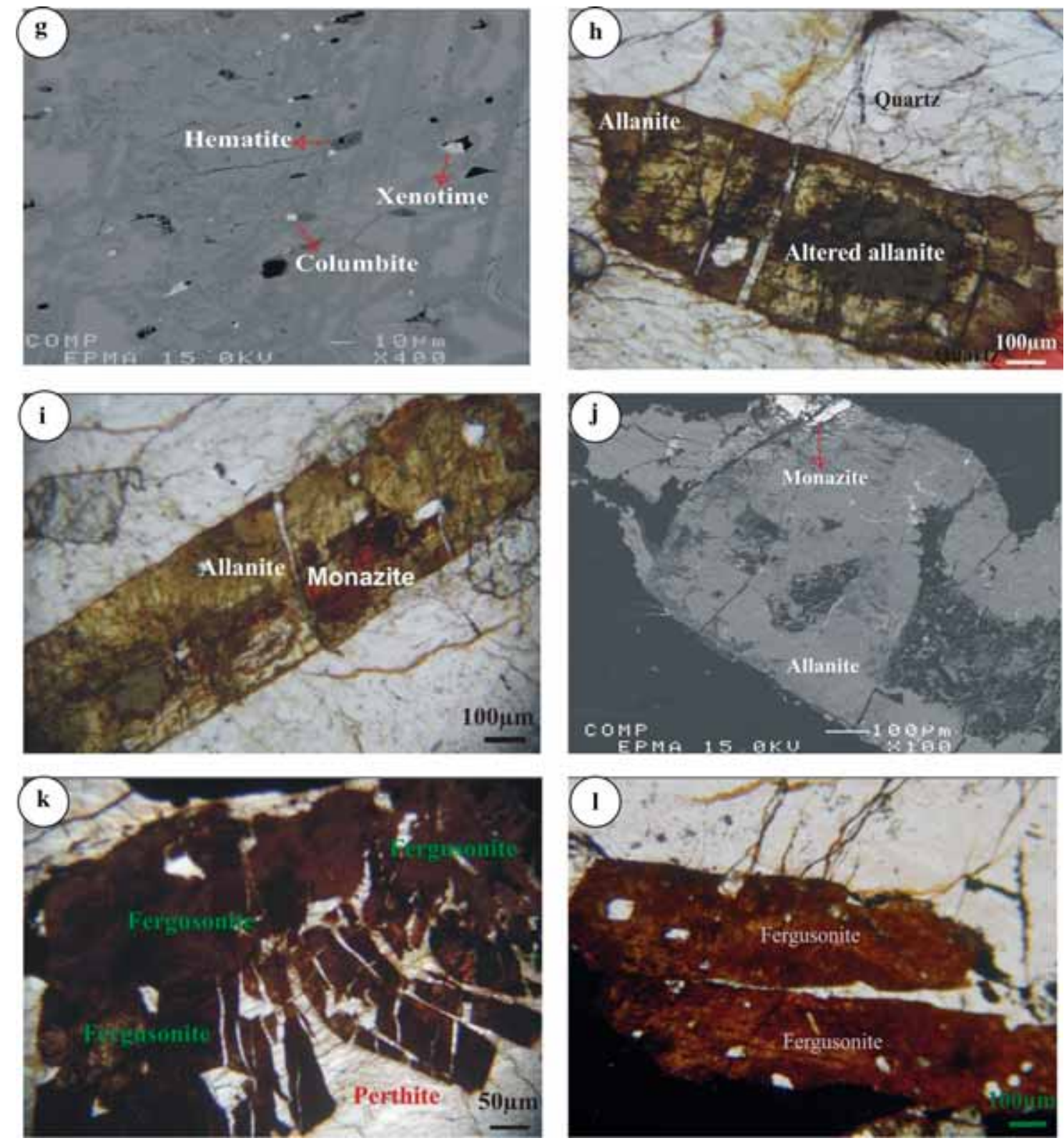

Figure 6. (Continued.)

$\mathrm{HREO}=1.46-1.97 \mathrm{wt} \%), \mathrm{Al}_{2} \mathrm{O}_{3} \quad(15.27-18.06$ wt\%), $\mathrm{Fe}_{2} \mathrm{O}_{3} \mathrm{t}(10.22-16.05 \mathrm{wt} \%)$ and $\mathrm{CaO}$ (7.51$9.46 \mathrm{wt} \%)$. MnO concentration is greater than $1 \mathrm{wt} \%$ and many other oxides are less than $1 \mathrm{wt} \%$. $\mathrm{ThO}_{2}$ is present whereas $\mathrm{UO}_{2}$ is not present or exists in a very limited amount, and $\mathrm{ThO}_{2} / \mathrm{UO}_{2}$ ratios are 0-199. Accordingly, they represent allanite-(Ce). The chondrite-normalised REE patterns of these crystals (figure 9) indicate that $(\mathrm{LREE})_{\mathrm{N}}$ values are very high relative to $(\mathrm{HREE})_{\mathrm{N}}$ values with a depletion of Eu. Additionally, the crystals show slight positive Ce anomalies. These indicate that the crystals originated from an oxygenated environment.
The semi-quantitative analyses by ESEM/EDX for magnetite (figure 10a) indicate that it contains $\mathrm{Fe}_{2} \mathrm{O}_{3}(98 \mathrm{wt} \%)$ and $\mathrm{TiO}_{2}(2 \mathrm{wt} \%)$. Titanomagnetite contains $\mathrm{Fe}_{2} \mathrm{O}_{3}$ (85.52 wt\%) and $\mathrm{TiO}_{2}$ (14.48 wt\%; figure 10b). Xenotime contains $\mathrm{Y}_{2} \mathrm{O}_{3}$ (46.4 wt\%), $\mathrm{P}_{2} \mathrm{O}_{5}$ (35.35 wt\%), $\mathrm{Gd}_{2} \mathrm{O}_{3}$ (2.61 wt\%), $\mathrm{Dy}_{2} \mathrm{O}_{3}(5.78 \mathrm{wt} \%), \mathrm{Er}_{2} \mathrm{O}_{3}(3.69 \mathrm{wt} \%)$ and $\mathrm{Yb}_{2} \mathrm{O}_{3}$ (2.81 wt\%), with some impurities of $\mathrm{Al}_{2} \mathrm{O}_{3}$ and $\mathrm{Fe}_{2} \mathrm{O}_{3} \mathrm{t}$ (figure 10c). Monazite-(Nd) contains $\mathrm{P}_{2} \mathrm{O}_{5}$ (17.97wt\%), $\mathrm{Nd}_{2} \mathrm{O}_{3}$ (24.28 wt\%), $\mathrm{Ce}_{2} \mathrm{O}_{3}$ (13.96 wt\%), $\mathrm{La}_{2} \mathrm{O}_{3}$ (8.71 wt\%), $\mathrm{Pr}_{2} \mathrm{O}_{3}(3.43 \mathrm{wt} \%)$ and $\mathrm{SiO}_{2}(5 \mathrm{wt} \%)$ as well as a high proportion of $\mathrm{ThO}_{2}(22.57 \mathrm{wt} \%)$ and $\mathrm{UO}_{2}$ (2.48 wt\%; figure 10d). This mineral also has $\mathrm{Al}_{2} \mathrm{O}_{3}(0.45 \mathrm{wt} \%)$ with high 


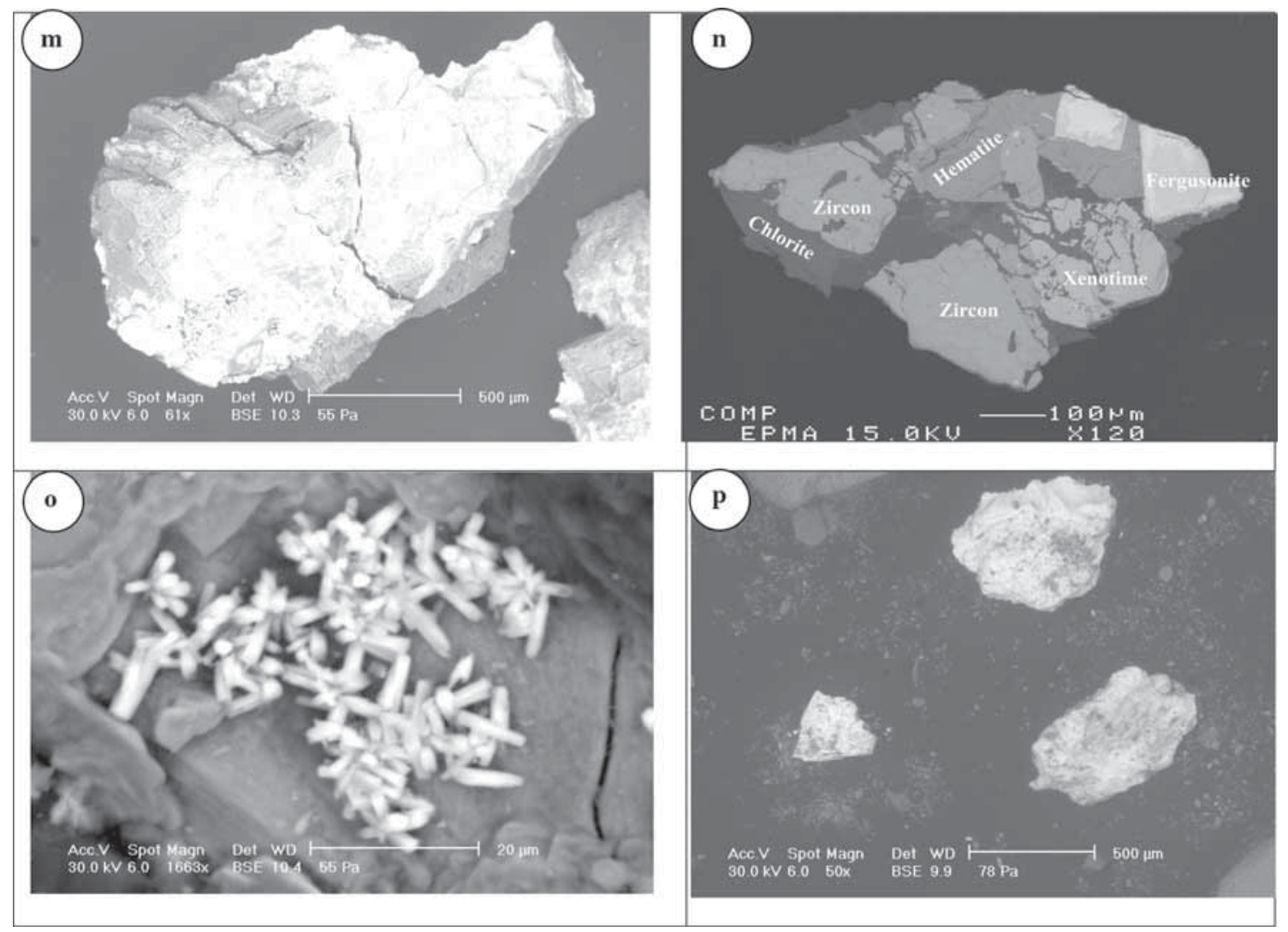

Figure 6. (Continued.)

concentrations of $\mathrm{Fe}_{2} \mathrm{O}_{3} \mathrm{t}$ (12.49wt\%) and $\mathrm{SiO}_{2}$ $(11.67 \mathrm{wt} \%)$, and these oxides may be a result of the groundmass. The thorite contains $\mathrm{UO}_{2}$ (7.65 wt\%), $\mathrm{ThO}_{2}$ (38.36 wt\%), $\mathrm{SiO}_{2}$ (14.85 wt\%) and $\mathrm{Fe}_{2} \mathrm{O}_{3} \mathrm{t}$ (11.0 wt\%; figure 10e), and additionally, $\mathrm{P}_{2} \mathrm{O}_{5}(15.27 \mathrm{wt} \%)$ and $\mathrm{Y}_{2} \mathrm{O}_{4}$ (4.86 wt\%), reflecting xenotime inclusions in the mineral, with some impurities of $\mathrm{CaO}, \mathrm{Al}_{2} \mathrm{O}_{3}$ and $\mathrm{TiO}_{2}$. Finally, gummite contains $\mathrm{UO}_{2}(74 \mathrm{wt} \%)$ and other oxides such as $\mathrm{SiO}_{2}$ (15.7 wt\%), $\mathrm{Al}_{2} \mathrm{O}_{3}$ (4.4 wt\%) and $\mathrm{CaO}$ (4wt\%; figure 10f).

\subsection{Whole-rock chemistry of pegmatites}

\subsubsection{Geochemical aspects of the pegmatite intermediate zones}

The rock-forming minerals of the pegmatite intermediate zones are quartz, magnetite and feldspars with a small amount of rare arfvedsonite. Zircon, fergusonite- $(\mathrm{Y})$, allanite- $(\mathrm{Ce})$ monazite, xenotime, columbite, thorite and gummite occur as trace/accessory minerals in some of the samples. The alteration product is represented by haematite and chlorite. The pegmatite intermediate zones contain a moderately high concentration of $\mathrm{SiO}_{2}$
(62.2-84.0 wt\%) and $\mathrm{Fe}_{2} \mathrm{O}_{3} \mathrm{t}$ (total iron as $\mathrm{Fe}_{2} \mathrm{O}_{3}$, $4.7-29.0 \mathrm{wt} \%$ ), where the iron concentration of the samples increased with the decreasing concentration of $\mathrm{SiO}_{2}$ (table 1), and low concentrations of $\mathrm{Al}_{2} \mathrm{O}_{3}, \mathrm{CaO}, \mathrm{Na}_{2} \mathrm{O}$ and $\mathrm{K}_{2} \mathrm{O}$ and the presence of $\mathrm{P}_{2} \mathrm{O}_{5}$ with limited concentrations or below detection limits were noticed. The concentration of $\mathrm{Ga}$ (up to $90 \mathrm{ppm}$ ) may be because $\mathrm{Ga}^{3+}$ was substituted for $\mathrm{Fe}^{3+}$ in the tetrahedral cation sites in magnetite and titaniferous magnetite (Vincent and Nightingale 1974). The pegmatites have high concentrations of Zr up to $28,984 \mathrm{ppm}$ (about $3 \mathrm{wt} \%$ ) with the lowest value of $579 \mathrm{ppm}, \mathrm{Nb}$ up to approximately $1 \mathrm{wt} \%$ with the lowest value of $915 \mathrm{ppm}$, Th up to $882 \mathrm{ppm}$ with the lowest value of $258 \mathrm{ppm}$, $\mathrm{U}$ up to $566 \mathrm{ppm}$ with the lowest value of $87 \mathrm{ppm}$, REE up to $19,206 \mathrm{ppm}$ with the lowest value of $2453 \mathrm{ppm}$ and the HREE are more predominantly over the LREE in most samples, while the Ta ranges from 26 to $152 \mathrm{ppm}$. These concentrations of all studied samples indicate that they are classified as rare-element pegmatites, NYF family (Černý 1991), where Zr, REE, Nb, Ti, Th, U > Ta, F.

There is a strong correlation between $U$ and Th in the studied pegmatites (figure 11a). These pegmatites have $\mathrm{Th} / \mathrm{U}$ ratios of $0.81-2.58$, which 


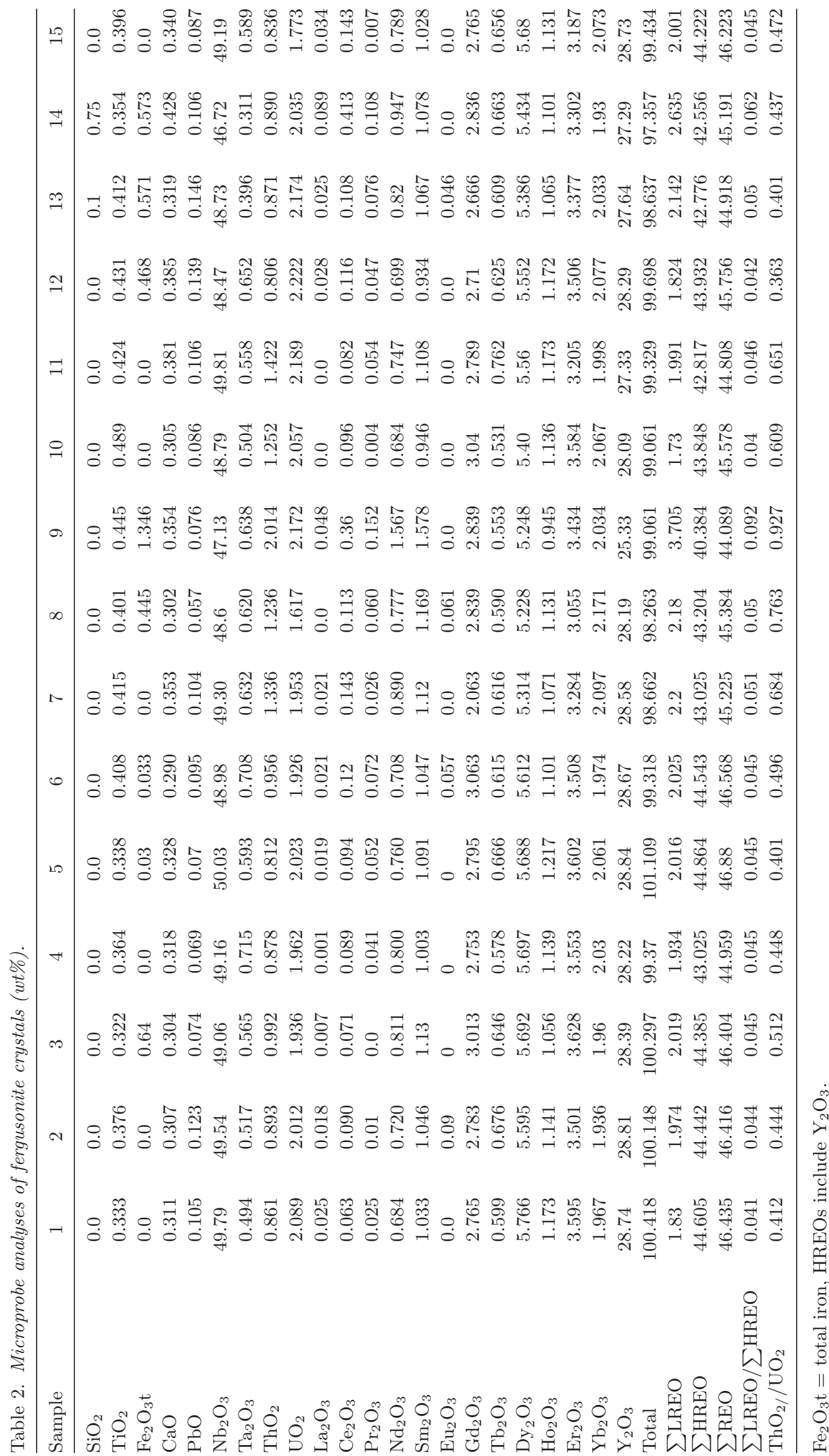




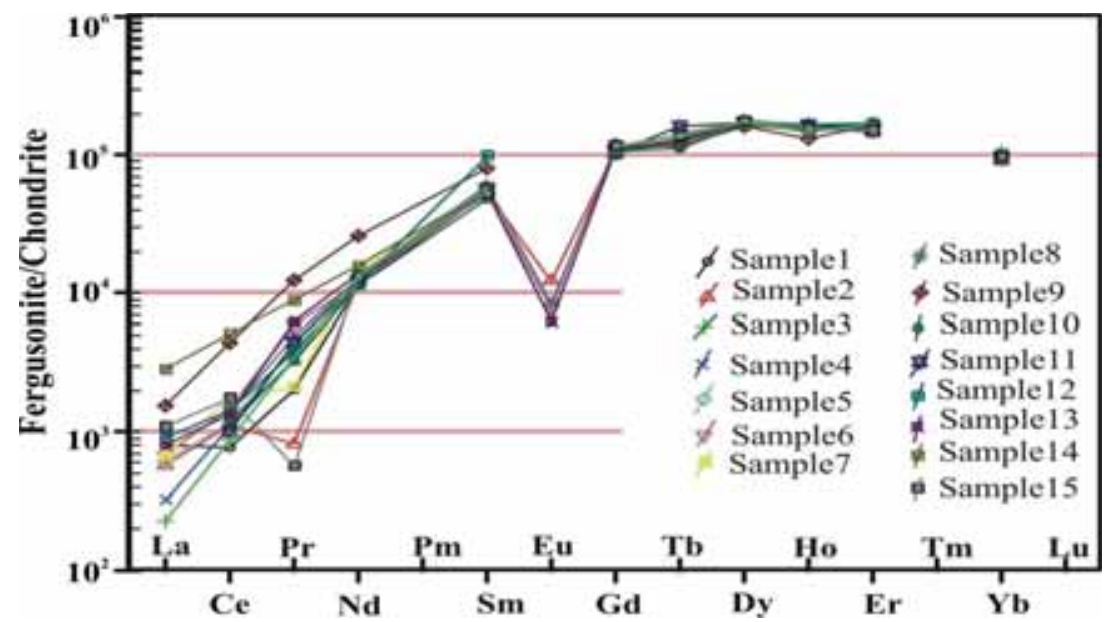

Figure 7. Chondrite-normalised REE profiles of the fergusonite crystals (Boynton 1984).

Table 3. Microprobe analyses of zircon crystals (wt\%).

\begin{tabular}{|c|c|c|c|c|c|c|c|}
\hline Sample & $1 \mathrm{rim}$ & 1 core & $2 \mathrm{rim}$ & 2 core & 3rim & 3 core & 4 core \\
\hline $\mathrm{SiO}_{2}$ & 32.97 & 32.93 & 32.96 & 33.00 & 32.81 & 32.49 & 32.84 \\
\hline $\mathrm{TiO}_{2}$ & 0.011 & 0.023 & 0.003 & 0.0 & 0.031 & 0.0 & 0.0 \\
\hline $\mathrm{Al}_{2} \mathrm{O}_{3}$ & 0.002 & 0.0 & 0.0 & 0.055 & 0.0 & 0.0 & 0.0 \\
\hline $\mathrm{Fe}_{2} \mathrm{O}_{3} \mathrm{t}$ & 0.0 & 0.0 & 0.005 & 0.003 & 0.0 & 0.0 & 0.0 \\
\hline $\mathrm{CaO}$ & 0.003 & 0.0 & 0.0 & 0.0 & 0.003 & 0.012 & 0.0 \\
\hline $\mathrm{P}_{2} \mathrm{O}_{5}$ & 0.312 & 0.395 & 0.337 & 0.740 & 0.293 & 0.892 & 0.377 \\
\hline $\mathrm{ZrO}_{2}$ & 64.07 & 64.19 & 63.54 & 64.17 & 64.34 & 63.80 & 63.58 \\
\hline $\mathrm{HfO}_{2}$ & 2.216 & 2.282 & 2.357 & 2.294 & 2.379 & 2.316 & 2.359 \\
\hline $\mathrm{Nb}_{2} \mathrm{O}_{3}$ & 0.111 & 0.131 & 0.182 & 0.123 & 0.109 & 0.092 & 0.106 \\
\hline $\mathrm{ThO}_{2}$ & 0.0 & 0.032 & 0.017 & 0.049 & 0.036 & 0.008 & 0.084 \\
\hline $\mathrm{UO}_{2}$ & 0.131 & 0.178 & 0.179 & 0.216 & 0.150 & 0.227 & 0.263 \\
\hline $\mathrm{Ce}_{2} \mathrm{O}_{3}$ & 0.026 & 0.021 & 0.0 & 0.0 & 0.037 & 0.022 & 0.01 \\
\hline $\mathrm{Nd}_{2} \mathrm{O}_{3}$ & 0.0 & 0.005 & 0.0 & 0.026 & 0.069 & 0.008 & 0.026 \\
\hline $\mathrm{Sm}_{2} \mathrm{O}_{3}$ & 0.0 & 0.02 & 0.029 & 0.0 & 0.0 & 0.052 & 0.0 \\
\hline $\mathrm{Eu}_{2} \mathrm{O}_{3}$ & 0.0 & 0.0 & 0.0 & 0.0 & 0.0 & 0.011 & 0.0 \\
\hline $\mathrm{Gd}_{2} \mathrm{O}_{3}$ & 0.0 & 0.0 & 0.0 & 0.135 & 0.089 & 0.086 & 0.093 \\
\hline $\mathrm{Tb}_{2} \mathrm{O}_{3}$ & 0.047 & 0.139 & 0.149 & 0.149 & 0.102 & 0.083 & 0.194 \\
\hline $\mathrm{Dy}_{2} \mathrm{O}_{3}$ & 0.101 & 0.046 & 0.060 & 0.093 & 0.024 & 0.044 & 0.029 \\
\hline $\mathrm{Ho}_{2} \mathrm{O}_{3}$ & 0.037 & 0.014 & 0.015 & 0.0 & 0.0 & 0.027 & 0.0 \\
\hline $\mathrm{Er}_{2} \mathrm{O}_{3}$ & 0.062 & 0.221 & 0.171 & 0.183 & 0.122 & 0.011 & 0.131 \\
\hline $\mathrm{Yb}_{2} \mathrm{O}_{3}$ & 0.040 & 0.085 & 0.122 & 0.101 & 0.097 & 0.150 & 0.182 \\
\hline $\mathrm{Y}_{2} \mathrm{O}_{3}$ & 0.116 & 0.184 & 0.196 & 0.149 & 0.113 & 0.222 & 0.580 \\
\hline Total & 100.255 & 100.896 & 100.332 & 101.486 & 100.804 & 100.553 & 100.854 \\
\hline$\sum L R E O$ & 0.026 & 0.046 & 0.029 & 0.026 & 0.106 & 0.093 & 0.036 \\
\hline$\sum H R E O$ & 0.403 & 0.689 & 0.713 & 0.81 & 0.547 & 0.623 & 1.209 \\
\hline$\sum \mathrm{REO}$ & 0.429 & 0.735 & 0.742 & 0.836 & 0.653 & 0.716 & 1.245 \\
\hline$\sum L R E O / \sum H R E O$ & 0.065 & 0.067 & 0.041 & 0.032 & 0.194 & 0.194 & 0.03 \\
\hline $\mathrm{ThO}_{2 /} / \mathrm{UO}_{2}$ & 0 & 0.18 & 0.09 & 0.23 & 0.24 & 0.03 & 0.32 \\
\hline
\end{tabular}

$\mathrm{Fe}_{2} \mathrm{O}_{3} \mathrm{t}=$ total iron, HREOs include $\mathrm{Y}_{2} \mathrm{O}_{3}$.

is lower than that of the upper part of the Earth's crust (3.8: Taylor and McClennan 1985), except sample $8(\mathrm{Th} / \mathrm{U}$ ratio $=6.61)$. These ratios indicate that these rocks are enriched in $\mathrm{U}$ relative to Th, except sample 8, and they might be enriched in the thorium minerals than uranium minerals or were subjected to the uranium migration as a result of the reactivation of the faults. The decrease in the $\mathrm{Th} / \mathrm{U}$ ratios with the increase in $\mathrm{SiO}_{2}$ (figure 11b) may be due to the uranium enrichment relative to 


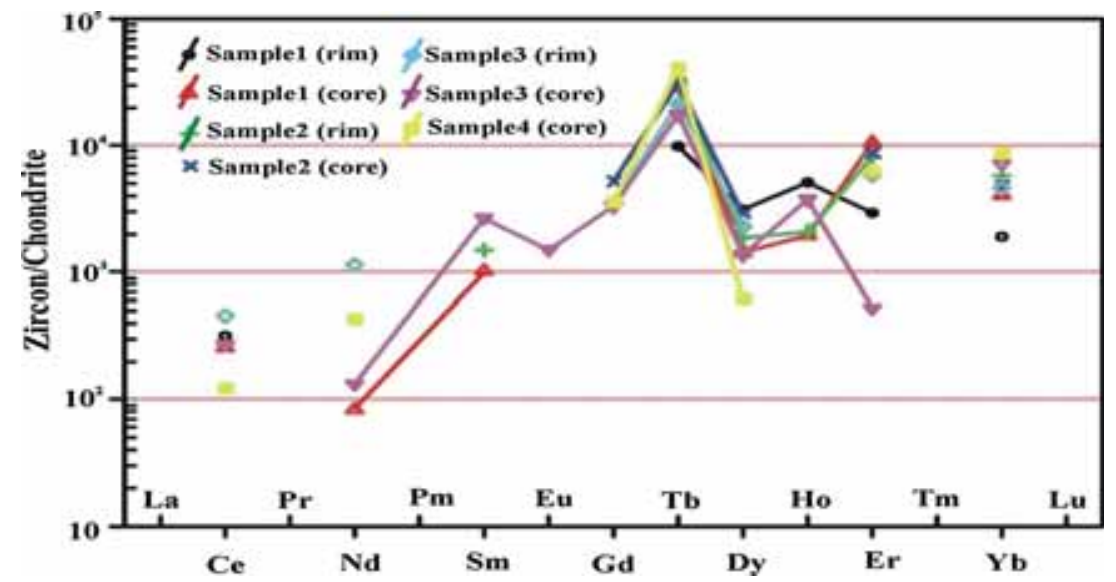

Figure 8. Chondrite-normalised REE profiles of the zircon crystals (Boynton 1984).

Table 4. Microprobe analyses of allanite crystals (wt\%).

\begin{tabular}{|c|c|c|c|c|c|c|c|c|}
\hline Sample & 1 & 2 & 3 & 4 & 5 & 6 & 7 & 8 \\
\hline $\mathrm{SiO}_{2}$ & 33.27 & 31.54 & 31.64 & 34.09 & 32.22 & 31.5 & 32.08 & 31.86 \\
\hline $\mathrm{TiO}_{2}$ & 0.425 & 0.380 & 0.398 & 0.484 & 0.367 & 0.341 & 0.419 & 0.422 \\
\hline $\mathrm{Al}_{2} \mathrm{O}_{3}$ & 18.06 & 16.57 & 15.27 & 17.61 & 17.17 & 16.23 & 16.87 & 16.64 \\
\hline $\mathrm{Fe}_{2} \mathrm{O}_{3} \mathrm{t}$ & 10.22 & 12.21 & 16.05 & 11.36 & 11.99 & 13.22 & 12.01 & 12.01 \\
\hline $\mathrm{CaO}$ & 7.517 & 8.265 & 9.458 & 7.882 & 7.865 & 7.695 & 8.061 & 8.249 \\
\hline $\mathrm{MgO}$ & 0.283 & 0.570 & 0.966 & 0.347 & 0.688 & 0.702 & 0.590 & 0.603 \\
\hline $\mathrm{Na}_{2} \mathrm{O}$ & 0.204 & 0.334 & 0.046 & 0.179 & 0.378 & 0.257 & 0.410 & 0.358 \\
\hline $\mathrm{K}_{2} \mathrm{O}$ & 0.024 & 0.014 & 0.014 & 0.035 & 0.02 & 0.022 & 0.021 & 0.019 \\
\hline $\mathrm{P}_{2} \mathrm{O}_{5}$ & 0.025 & 0.013 & 0.031 & 0.029 & 0.020 & 0.009 & 0.020 & 0.015 \\
\hline $\mathrm{MnO}$ & 1.281 & 1.103 & 1.172 & 1.291 & 1.002 & 1.289 & 1.119 & 1.079 \\
\hline $\mathrm{SrO}$ & 0.096 & 0.103 & 0.003 & 0.108 & 0.144 & 0.027 & 0.144 & 0.111 \\
\hline $\mathrm{PbO}$ & 0.075 & 0.045 & 0.013 & 0.083 & 0.008 & 0.023 & 0.035 & 0.049 \\
\hline $\mathrm{ThO}_{2}$ & 0.656 & 0.762 & 0.530 & 0.597 & 0.697 & 0.737 & 0.769 & 0.711 \\
\hline $\mathrm{UO}_{2}$ & 0.0 & 0.0 & 0.0 & 0.003 & 0.0 & 0.018 & 0.0 & 0.02 \\
\hline $\mathrm{F}$ & 0.149 & 0.173 & 0.155 & 0.131 & 0.170 & 0.073 & 0.080 & 0.150 \\
\hline $\mathrm{Cl}$ & 0.326 & 0.027 & 0.023 & 0.156 & 0.024 & 0.047 & 0.042 & 0.024 \\
\hline $\mathrm{La}_{2} \mathrm{O}_{3}$ & 3.404 & 3.278 & 3.760 & 3.472 & 3.425 & 3.489 & 3.432 & 3.129 \\
\hline $\mathrm{Ce}_{2} \mathrm{O}_{3}$ & 10.74 & 10.32 & 10.90 & 10.28 & 10.52 & 10.78 & 10.70 & 10.28 \\
\hline $\mathrm{Pr}_{2} \mathrm{O}_{3}$ & 1.317 & 1.263 & 1.412 & 1.314 & 1.308 & 1.444 & 1.347 & 1.347 \\
\hline $\mathrm{Nd}_{2} \mathrm{O}_{3}$ & 5.359 & 5.601 & 5.40 & 5.201 & 5.689 & 5.066 & 5.552 & 5.594 \\
\hline $\mathrm{Sm}_{2} \mathrm{O}_{3}$ & 0.887 & 1.051 & 0.909 & 0.780 & 1.029 & 1.222 & 1.056 & 1.156 \\
\hline $\mathrm{Gd}_{2} \mathrm{O}_{3}$ & 0.515 & 0.635 & 0.531 & 0.487 & 0.613 & 0.728 & 0.622 & 0.692 \\
\hline $\mathrm{Dy}_{2} \mathrm{O}_{3}$ & 0.099 & 0.159 & 0.199 & 0.122 & 0.146 & 0.169 & 0.199 & 0.229 \\
\hline $\mathrm{Y}_{2} \mathrm{O}_{3}$ & 0.911 & 1.038 & 0.891 & 0.850 & 0.932 & 0.921 & 0.977 & 1.048 \\
\hline Total & 95.843 & 95.454 & 99.771 & 96.891 & 96.425 & 96.009 & 96.555 & 95.795 \\
\hline ¿LREO & 21.707 & 21.513 & 22.381 & 21.047 & 21.971 & 22.001 & 22.087 & 21.506 \\
\hline$\sum H R E O$ & 1.525 & 1.832 & 1.621 & 1.459 & 1.691 & 1.818 & 1.798 & 1.969 \\
\hline$\sum R E O$ & 23.232 & 23.345 & 24.002 & 22.506 & 23.662 & 23.819 & 23.885 & 23.475 \\
\hline 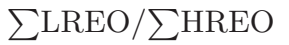 & 14.234 & 11.743 & 13.807 & 14.426 & 12.993 & 12.102 & 12.284 & 10.922 \\
\hline $\mathrm{ThO}_{2 /} / \mathrm{UO}_{2}$ & 0 & 0 & 0 & 199 & 0 & 40.94 & 0 & 35.55 \\
\hline
\end{tabular}

$\mathrm{Fe}_{2} \mathrm{O}_{3} \mathrm{t}=$ total iron, HREOs include $\mathrm{Y}_{2} \mathrm{O}_{3}$. 


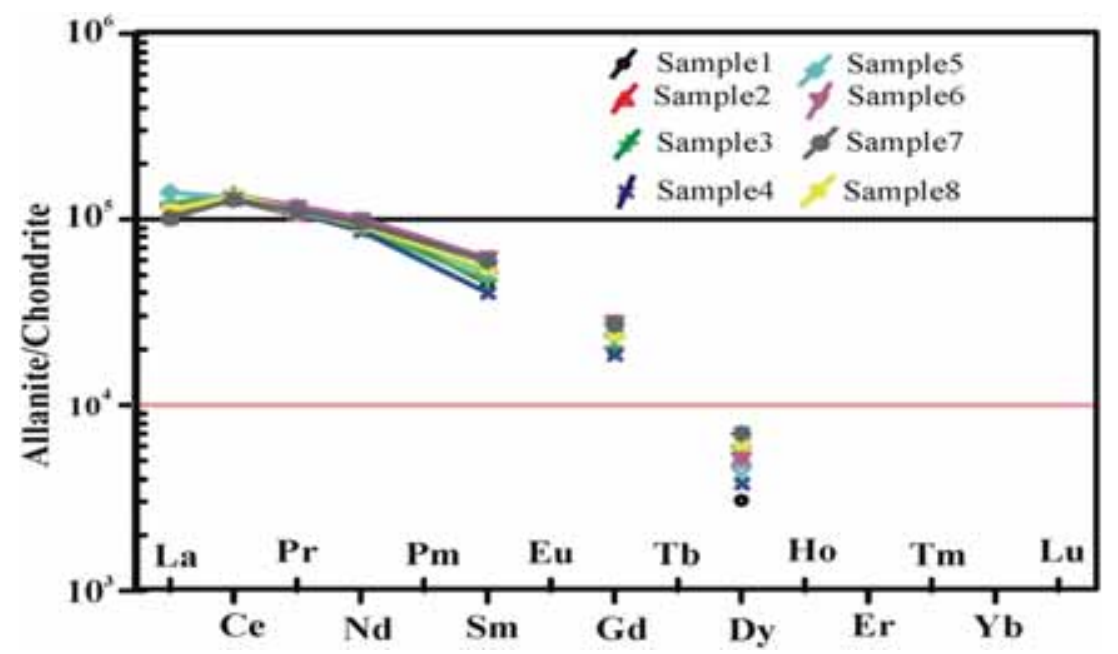

Figure 9. Chondrite-normalized REE profiles of the allanite crystals (Boynton 1984).

thorium because $\mathrm{U}$ entered into an aqueous phase as uranyl ions during the final stages of crystallisation of granitic magmas (pegmatite). Furthermore, the strong correlation between $\Sigma$ REE and both Th and U (figure 11c and d) occurs as a result of the strong link between $\mathrm{Th}$ and $\mathrm{U}$ in monazite- $(\mathrm{Ce}$ and $\mathrm{Nd}$ ), xenotime and fergusonite minerals which have considerable concentrations of Th and U. The correlation and variations of $\mathrm{Nb} / \mathrm{Ta}$ and $\mathrm{Zr} / \mathrm{Hf}$ indicate a moderate to high degree of fractionation in the NYF-type pegmatite melts of Gabal El Faliq (figure $12 \mathrm{a}-\mathrm{c}$ ). The $\mathrm{Nb} / \mathrm{Ta}$ ratios in the studied pegmatites range from 10.76 to 81.67 with an average of 45.55 . $\mathrm{Nb} v s$. the $\mathrm{Nb} / \mathrm{Ta}$ ratios show a moderate positive relation (figure $12 \mathrm{~b}$ ). The $\mathrm{Zr} / \mathrm{Hf}$ ratios range from 14.9 to 25.96 with an average of 22.39 ; there is variability in $\mathrm{Hf}$, with relatively constant $\mathrm{Zr} / \mathrm{Hf}$ ratios (figure 12c).

The chondrite-normalised REE patterns of the pegmatite intermediate zones (figure 13) show relatively similar flat patterns with negative europium anomalies $\left(\mathrm{Eu} / \mathrm{Eu}^{*}=0.05-0.12\right)$. Samples with a lower total REE show a lower content of LREE. Overall, REE patterns are characterised by HREE enrichment relative to LREE.

\subsubsection{Tectonic setting and petrogenesis}

The high $\mathrm{Fe} / \mathrm{Mg}, \mathrm{Zr}, \mathrm{Nb}, \mathrm{Ga}, \mathrm{REE}, \mathrm{Y}$ and $\mathrm{F}$ contents are features of A-type granite geochemistry (e.g., Collins et al. 1982; Whalen et al. 1987; Eby 1990). The NYF pegmatites are characterised by $\mathrm{Nb}>\mathrm{Ta}$ (Černý and Ercit 2005). The ternary diagrams of $\mathrm{Y}-\mathrm{Nb}-3 \mathrm{Ga}$ and the $\mathrm{Y}-\mathrm{Nb}-\mathrm{Ce}$ (Eby 1992) that discriminate between different types of granites (figure 14a and b) indicate that the NYF pegmatites fall completely within the field $\mathrm{A}_{1}$ of mantle-derived magma. The magma was emplaced along the Wadi El Gemal strike-slip fault within a continental plate (figure 14c) and was subjected to prolonged fractionation to form these pegmatite dykes (figure 15).

The petrogenesis of the Gabal El Faliq pegmatites may be reflected in the geochemistry of their trace elements. Melts derived from the mantle with little crustal contamination are reflected by low Cs $(<5 \mathrm{ppm})$ and high Rb/Cs ( $>40$; Scarrow et al. 2009). The studied Gabal El Faliq pegmatites have low Cs $(<0.1-0.3 \mathrm{ppm})$ and high $\mathrm{Rb} / \mathrm{Cs}$. These ratios suggest a mantle-derived origin. Furthermore, the enrichment in REE with predominant HREE and the absence of $\mathrm{Nb}$ depletion in these rocks reflect an intracontinental tectonic setting similar to the Kola Peninsula, Russia (Kogarko et al. 2002). The depletion in Ba, Sr, P and Ti (figure 16) indicates a strong mantle-derived source for these rocks similar to that of the alkaline volcanic rocks derived from the alkali basalt magmas of Lake Chad (Mbowou et al. 2012). These results are also consistent with the opinion of Martin and De Vito (2005), who suggested that the NYFtype deposits occur in anorogenic tectonic settings and are ultimately mantle-derived (London 2008). Low $\mathrm{Y} / \mathrm{Nb}$ ratios $(<1.2)$ provide evidence for their origin from mantle-derived magma similar to the oceanic island basalts (OIBs) as suggested by Eby (1990; figure 15). This diagram shows the studied pegmatite sample plots within the OIB field and the differentiation trend of AF emanating from this field. 


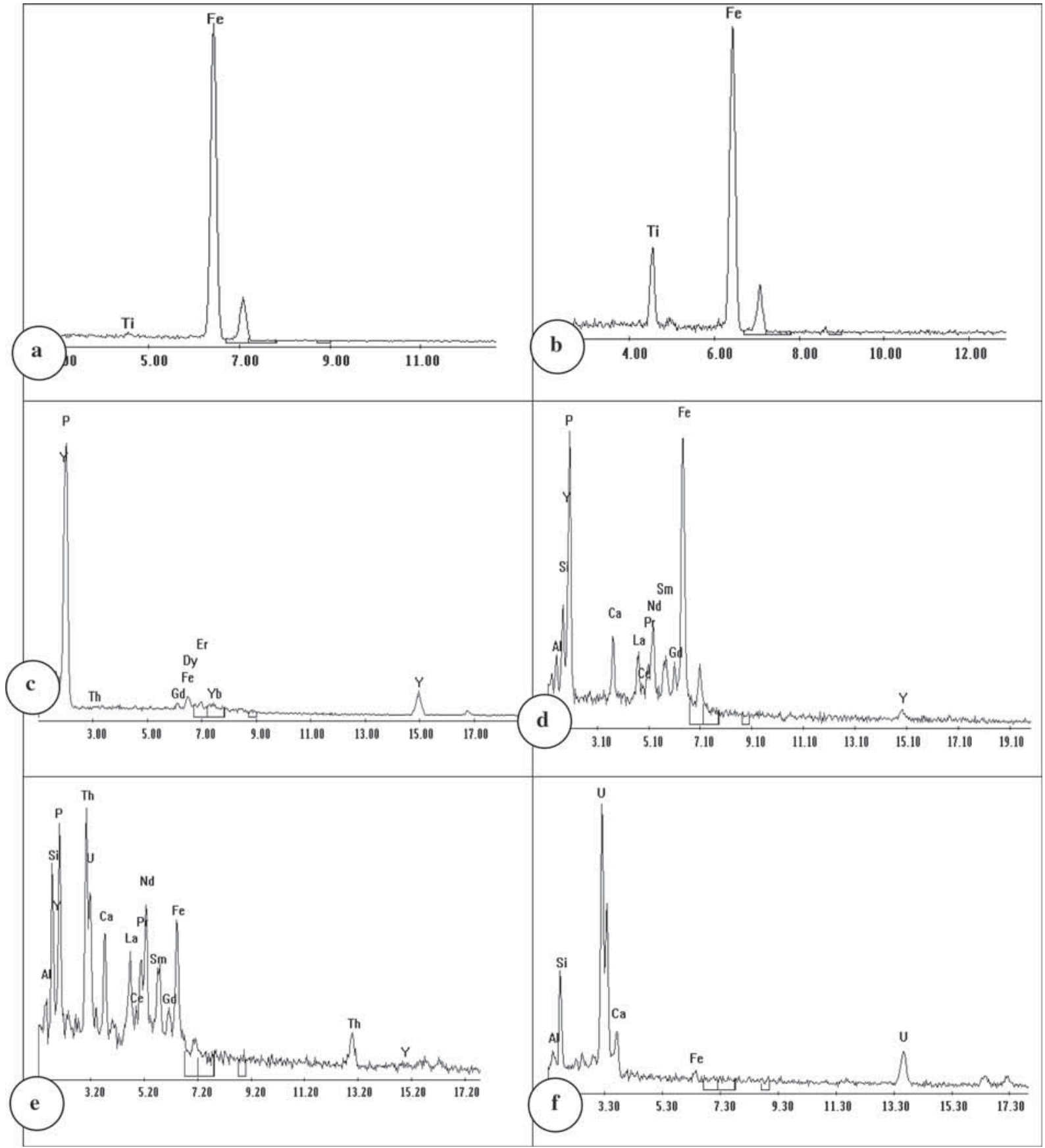

Figure 10. ESEM/EDX pattern of (a) magnetite, (b) titanomagnetite, (c) xenotime, (d) monazite-(Nd), (e) thorite and (f) gummite.

\section{Discussion and interpretations}

The Gabal El Faliq leucogranites host dykes and lenses of rare metal-bearing pegmatites, located in the Southeastern Desert of Egypt in the southwestern segment of the Wadi Hafafit-Wadi Ghadir fold belt. The Wadi Hafafit-Wadi Ghadir fold belt, formed during the Pan-African orogeny, consists of two main groups that were separated by a major thrust called Nugrus (figure 2a). In the late Pan-African orogeny, many leucogranites were formed in the Wadi Hafafit-Wadi Ghadir fold belt along the Nugrus thrust zone and its branches (e.g., Wadi El Gemal thrust) as the Gabal El Faliq leucogranites, which were formed by the partial melting of the thickened crust (Abd El-Naby and Frisch 2006). This event was accompanied by the reactivation of the old thrust zones as strikeslip faults or shear zones (Moghazi et al. 2004). Accordingly, the major Wadi El Gemal strike-slip 

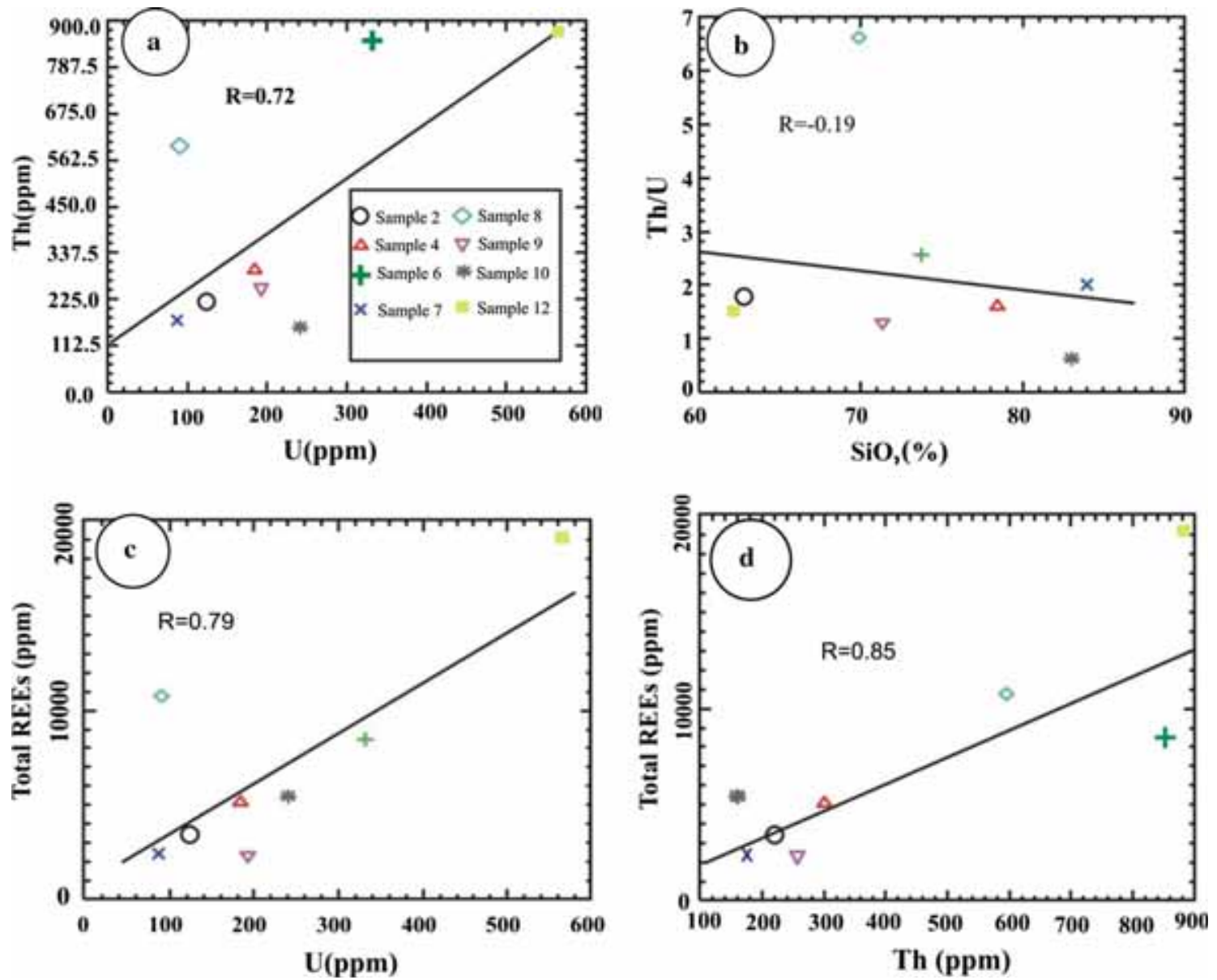

Figure 11. (a) U vs. Th binary variation diagram, (b) $\mathrm{SiO}_{2} \%$ vs. Th/U binary variation diagram, (c) U vs. total REEs binary variation diagram and (d) Th vs. total REEs binary variation diagram for the studied pegmatite intermediate zones.

motion would produce a mantle-derived magma. This magma is easily contaminated by the country rocks due to its relatively prolonged crystallisation time and/or shear heating. As a result, the rare metal-bearing pegmatites were formed from the residual melts of the prolonged fractionation of a previously contaminated magma. These rare metal-bearing pegmatites exist as dykes that were injected into the fractures of the Gabal El Faliq area.

The mineral chemistry indicated that fergusonite crystals (table 2) are composed of $\mathrm{Nb}_{2} \mathrm{O}_{5}$ (46.72-50.03 wt\%), $\mathrm{Y}_{2} \mathrm{O}_{3}$ (27.29-28.84 wt\%), with total HREO, including $\mathrm{Y}_{2} \mathrm{O}_{3}$ (40.38-44.86 wt\%), and LREO (1.73-3.71 wt\%), as well as a significant concentration of $\mathrm{UO}_{2}(1.62-2.19 \mathrm{wt} \%)$ and $\mathrm{ThO}_{2}$ (0.81-2.01 wt\%). The chondrite-normalised REE patterns of fergusonite crystals show that the HREE values are very high relative to the LREE values with depleted or pronounced negative Euanomalies. On the other hand, some samples show positive $\mathrm{Ce}$ anomalies and negative $\operatorname{Pr}$ anomalies at the same time which is due to the crystals that were subjected to the hydrothermal metasomatism which led to variable Ce anomalies (Bagiński et al. 2016). Accordingly, a positive Ce anomaly causes an apparent negative $\mathrm{Pr}$ anomaly. Variable $\mathrm{Ce}$ anomalies also can be attributed to an oxygenated environment, where redox conditions changed during the formation of pegmatite. This fact is due to the presence of arfvedsonite which indicates reducing conditions and high water pressure, but the presence of haematite indicates oxidising conditions. Accordingly, the mineral assemblage of pegmatites took place in two stages: the first stage was reducing conditions and it was appropriated to form arfvedsonite, but the second stage was oxidising conditions where the replacement of magnetite and mafic minerals by haematite took place and extensive quartz was formed. Zircon crystals are composed of $\mathrm{ZrO}_{2}(63.54-64.34 \mathrm{wt} \%)$ and $\mathrm{SiO}_{2}$ (32.49-33 wt\%) with a significant amount of $\mathrm{HfO}_{2}$ $(2.22-2.29 \mathrm{wt} \%)$, an average of $2.31 \mathrm{wt} \%$. This average is closer to the lower value of $\mathrm{HfO}_{2}(2.4 \mathrm{wt} \%)$ 

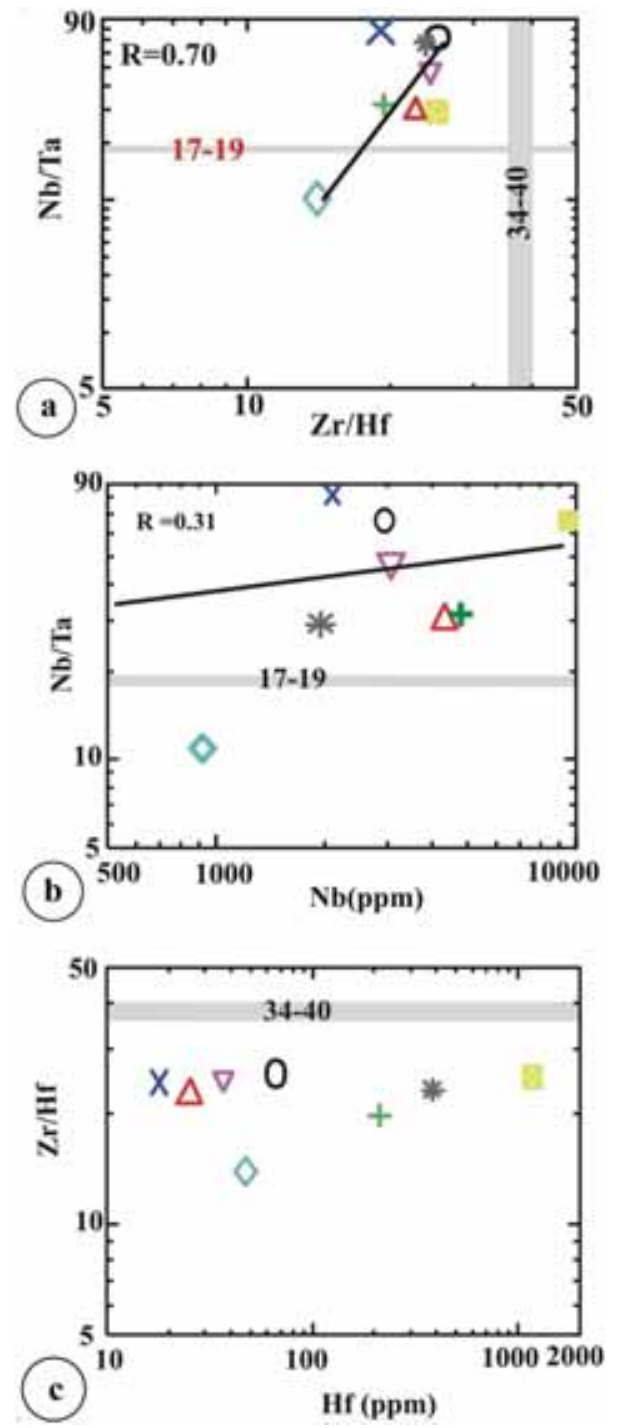

Figure 12. (a) $\mathrm{Zr} / \mathrm{Hf}$ vs. $\mathrm{Nb} / \mathrm{Ta}$ binary variation diagram, (b) $\mathrm{Nb}$ vs. $\mathrm{Nb} / \mathrm{Ta}$ binary variation diagram and (c) Hf vs. Hf/Zr binary variation diagram. that was recorded in zircon from the Beauvoir pegmatite (France) by Wang et al. (1992). Allanite crystals are composed of $\mathrm{SiO}_{2}(31.50-34.09 \mathrm{wt} \%)$, REO (22.51-24.00 wt\%), mostly LREO (21.047$22.38 \mathrm{wt} \%), \quad \mathrm{Al}_{2} \mathrm{O}_{3} \quad(15.27-18.06 \mathrm{wt} \%), \quad \mathrm{Fe}_{2} \mathrm{O}_{3} \mathrm{t}$ (10.22-16.05 wt\%) and $\mathrm{CaO}$ (7.51-9.46 wt\%). Additionally, $\mathrm{ThO}_{2}$ exists in these crystals whereas $\mathrm{UO}_{2}$ either exists or does not exist (table 4).

The fractional crystallisation processes and volatiles were responsible for the high concentrations of $\mathrm{Zr}$, Hf, REE, $\mathrm{U}$ and $\mathrm{Th}$ in the pegmatite intermediate zones, where $\mathrm{Zr}$ was up to $3 \mathrm{wt} \%$, Hf up to $0.12 \mathrm{wt} \%$, Nb up to $1 \mathrm{wt} \%$, Ta up to $0.015 \mathrm{wt} \%$, REEs up to $2 \mathrm{wt} \%$, U up to $0.06 \mathrm{wt} \%$, Th up to 0.09 wt $\%$ and Ga was up to 0.009 wt $\%$, so they were classified as the NYF pegmatites. The REE patterns of fergusonite (figure 7), allanite (figure 8), zircon (figure 9) and bulk samples of pegmatite intermediate zones (figure 13) show depleted, weak negative Eu anomalies and enrichment of REE. This indicated that the nature of residual pegmatite magma is characterised by (i) extreme enrichment in volatiles with very low viscosity (Baker and Vaillancourt 1995), despite its low temperature, (ii) strong depletion in feldsparcompatible elements and (iii) higher abundances of HFSE cations. Redistribution of elements took place by the hydrothermal solutions (Bau and Dulski 1999).

On the other hand, the internally derived mineralising fluids during the fractionation crystallisation processes have modified ratios, such as $\mathrm{Nb} / \mathrm{Ta}$ and $\mathrm{Zr} / \mathrm{Hf}$ (figure 12a). These ratios have been used to show fractionation in other rare metal granitic pegmatites (e.g., Linnen 1998).

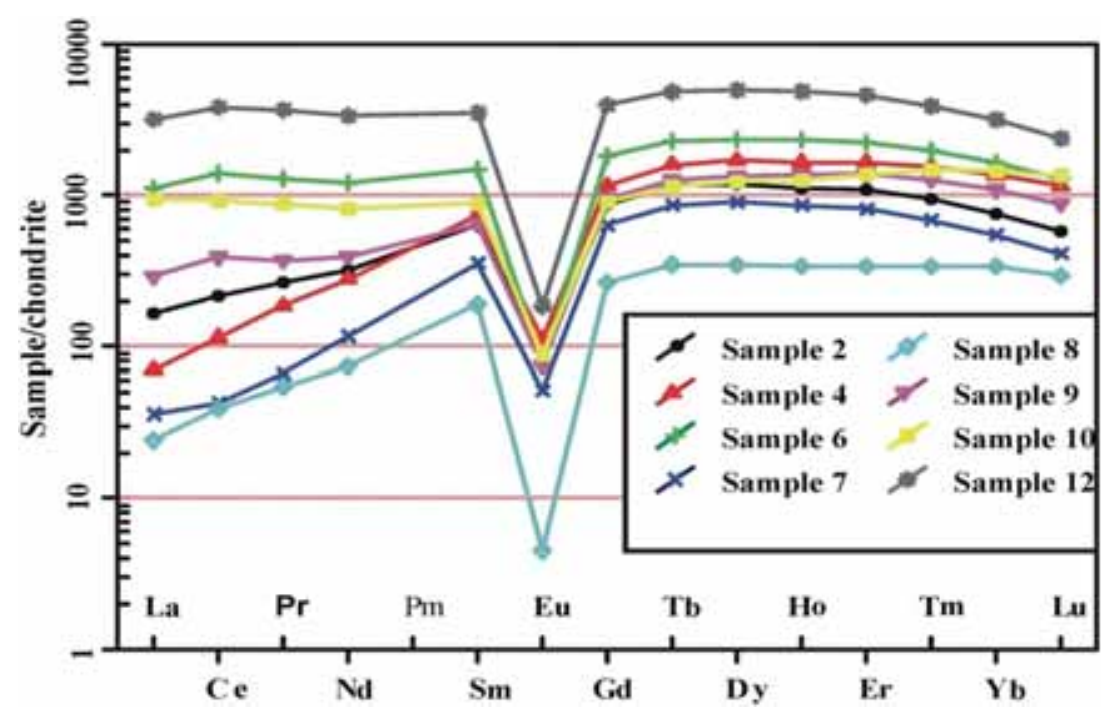

Figure 13. Chondrite-normalised REE profiles of the pegmatite intermediate zones (after Boynton 1984). 

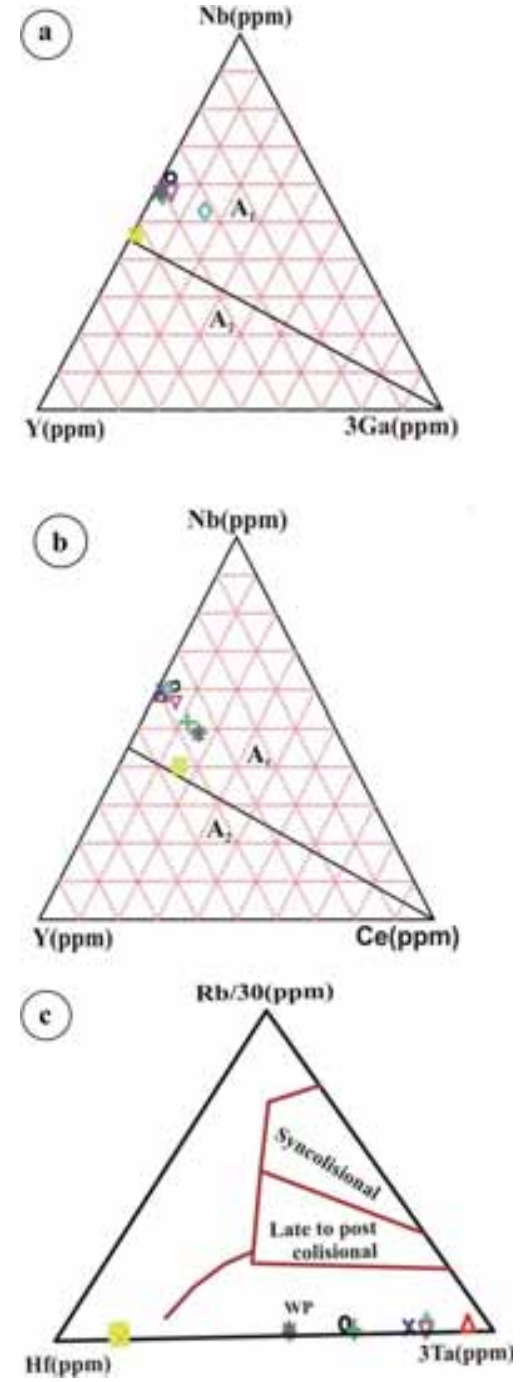

Figure 14. (a) Ternary plot $\mathrm{Y}-\mathrm{Nb}-3 \mathrm{Ga}$ for the pegmatite intermediate zones (Eby 1992). (b) Ternary plot $\mathrm{Y}-\mathrm{Nb}-$ $\mathrm{Ce}$ for the pegmatite intermediate zones (Eby 1992). (c) Ternary plot HF-Rb/30-3Ta for the pegmatite intermediate zones (Harris et al. 1986). Symbols are as in figure 11.

The intermediate zones of Gabal El Faliq pegmatites show a distinct fractionation trend when comparing $\mathrm{Nb} / \mathrm{Ta}$ vs. $\mathrm{Nb}$ (figure $12 \mathrm{~b}$ ). This diagram shows that the $\mathrm{Nb} / \mathrm{Ta}$ ratio increases with increasing $\mathrm{Nb}$. This result can be attributed to the low concentration of hydrofluoric acid (HF) at a low $\mathrm{pH}$, where $\mathrm{Nb}$ is more soluble than $\mathrm{Ta}$ in acidic hydrothermal fluids that have low concentrations of HF (Timofeev et al. 2017). This is consistent with the present study, where fluorine is found only in allanite, and may also be due to the occurrence of phosphorus, which only increases columbite solubility (Wolf and London 1993) in the residual granitic melt that formed pegmatite. The retention of $\mathrm{Nb}$ in acidic hydrothermal fluids may be responsible for the increase of $\mathrm{Nb} / \mathrm{Ta}$

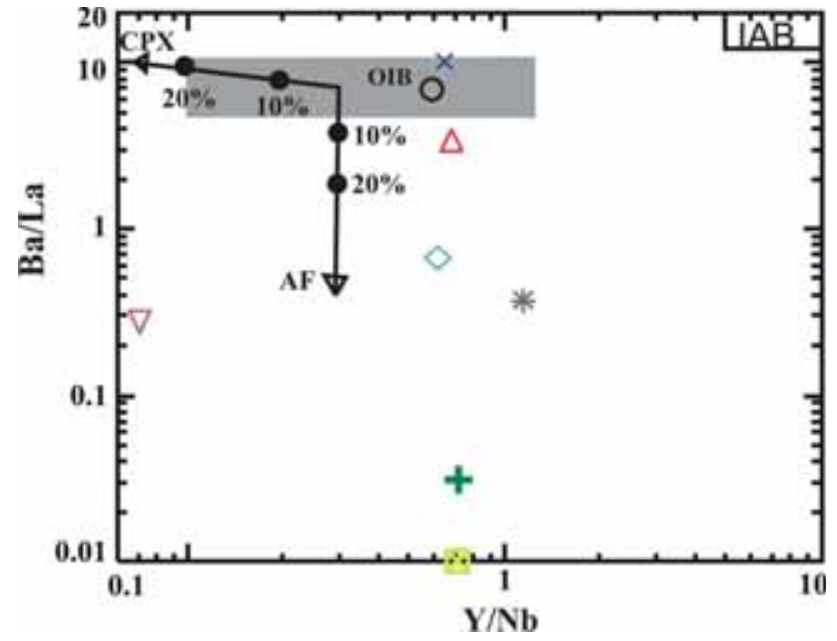

Figure 15. Y/Nb vs. Ba/La binary variation diagram (Eby 1990). Symbols are as in figure 11; OIB, IAB = island arc basalts, CPX and AF. Fractionation trends calculated using partition coefficients of Henderson (1982).

ratios in residual pegmatite melts. Accordingly, the $\mathrm{Nb} / \mathrm{Ta}$ ratios for the studied intermediate zones of pegmatites (table 1) are more than the chondritic values (17 \pm 1 , Weyer et al. 2002). The $\mathrm{Zr} / \mathrm{Hf}$ ratios are relatively constant for the studied pegmatites (figure 12c) with an increasing Hf, and the fact could be explained by the lower crystallisation temperature, which increases the diffusion coefficient of hydrogen in hafnium (DHf) between zircon and pegmatite magma (Wang et al. 2010). Furthermore, their $\mathrm{Zr} / \mathrm{Hf}$ ratios range from 14.1 to 25.96 with an average of 22.39. This average (about 25) is mostly close to the average $\mathrm{Zr} / \mathrm{Hf}$ in 107 whole-rock analyses of pegmatites (Erlank et al. 1978), but it is less than the chondritic values $(36.6 \pm 2.9$; Bau 1996) for unfractionated igneous rocks.

As for the origin, this study mentioned many evidences that supported the origin of the Gabal El Faliq NYF-type granitic pegmatite from prolonged fractionation basaltic magma (similar to the OIB magmas), coming from the mantle as a result of the reactivation of the Wadi El Gemal thrust as a strike-slip fault that was accompanied by the regional strike-slip faults and shear zones that were formed in the Hafafit-Ghadir fold belt after a late Pan-African orogeny (Moghazi et al. 2004). These suggest that pegmatites are emplaced into the non-orogenic setting (figure 14c), enriched in REE, Nb, Zr, Hf, Th, U and Ga and depletion of $\mathrm{Ba}, \mathrm{Sr}, \mathrm{P}$ and $\mathrm{Ti}$ (figure 16). The low $\mathrm{Y} / \mathrm{Nb}$ ratios $(<1.2$; figure 15$)$ that indicate the most samples of parental melt of Gabal El Faliq 


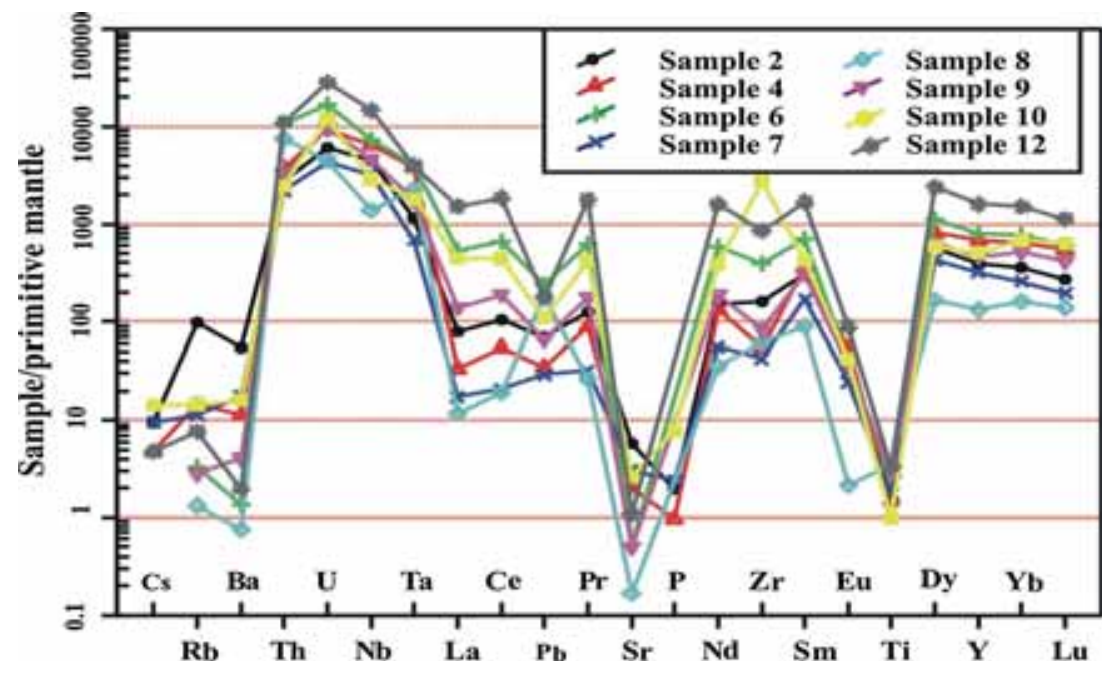

Figure 16. Spider diagrams of the studied pegmatite intermediate zones (McDonough and Sun 1995).

rare metal-bearing pegmatites are located under the OIBs field. This phenomenon shows that the pegmatite melt underwent high AF fractionation in the presence of volatiles (Eby 1990, 1992). Additionally, the $\mathrm{Y} / \mathrm{Nb}$ ratio is virtually unchanged over the wide range of silica values for any particular suite (Eby 1990), where clinopyroxenes (CPXs) and amphiboles of the common silicate minerals would be significant phases during fractional crystallisation. CPXs or/and amphiboles fractionation will significantly change the $\mathrm{Y} / \mathrm{Nb}$ ratio but cocrystallisation of a Ti-rich phase would lower $\mathrm{Nb}$ relative to Y (Green and Pearson 1986), thus, the $\mathrm{Y} / \mathrm{Nb}$ ratio remains relatively constant during the fractionation processes.

The enrichment of rare elements is usually associated with higher concentrations of fluxing components such as $\mathrm{F}, \mathrm{P}$ and $\mathrm{H}_{2} \mathrm{O}$ (Linnen 1998) such as the studied rocks. These fluxing elements played an important role in pegmatitic magma evolution by causing significant changes in the residual melt structure that affects melt properties such as viscosity and diffusivity (London 2008). The confirmation of fluxing element effects is derived from the recent experimental studies by Migdisov and Williams-Jones (2002, 2007) and Migdisov et al. (2009), which indicated that $\mathrm{Zr}$ and REE form complexes with fluoride and the fluids with $\mathrm{HF}$ concentration at $0.1 \mathrm{~m}$ that can dissolve $10 \mathrm{ppm}$ of zircon and higher concentrations of REE at $200^{\circ} \mathrm{C}$. Alternatively, only phosphorus increases columbite solubility (Wolf and London 1993). Accordingly, the high concentration mechanism for the saturation of the Zr-, Nb-, Th-, U- and REE-bearing pegmatites at Gabal El Faliq is because phosphorus and fluorine reduce solidus temperatures, decrease viscosity and increase the solubility of $\mathrm{H}_{2} \mathrm{O}$ in the melt (Dingwell et al. 1996; London 1997, 2009). Consequently, the fluorine could have led to rare elements transport in hydrothermal fluids mainly as fluoride complexes, and the deposition of these element-bearing minerals at Gabal El Faliq from the fluoride complexes could have taken place as a result of the interaction of such Ca-poor, F-fluids with Ca-bearing rocks (Salvi and Williams-Jones 2004).

In general, these rocks can be compared with the alkaline rocks in Egypt, in their alkaline parent magma, where El-Ramly and Hussein (1982) suggested that these rocks were formed under certain favourable geotectonic conditions (e.g., intracontinental hot spots) and a partial fusion of deeper levels in the upper mantle could produce enough heat and volatiles (Lameyre et al. 1984; Black et al. 1985).

\section{Conclusions}

(a) The Gabal El Faliq rare metal-bearing pegmatites were formed as a result of mantlederived magma contaminated with the lower crust.

(b) The contaminated magma underwent prolonged crystallisation during its ascent in the Wadi El Gemal strike-slip fault and its Riedel shears and in so doing achieved a felsic composition. Early pulses of magma are thought 
not to have contained any significant amounts of HFSEs (Zr, Hf, REE, Nb, Ta, U, Th and $\mathrm{Ga}$ ) which led to the increase in their concentrations in the residual melt.

(c) The pegmatite bodies are mineralogically complex types and consist mainly of quartz and magnetite, feldspars, haematite and rare arfvedsonite. They are zoned with a high abundance of rare metal-bearing minerals in their intermediate zones. These include fergusonite$(\mathrm{Y})$, zircon and allanite- $(\mathrm{Ce})$, in addition to monazite-(Ce and Nd), xenotime-(Y) and columbite- $(\mathrm{Fe})$, thorite and gummite.

(d) The high concentrations of Zr-, Nb-, Th-, Uand REE-bearing pegmatites at the Gabal El Faliq are likely to be due to the presence of phosphorus and fluorine, which reduce solidus temperatures, decrease viscosity and increase the solubility of $\mathrm{H}_{2} \mathrm{O}$ in the melt.

(e) The binary diagrams of the geochemical data of the studied pegmatites support a fractionation model of the Gabal El Faliq NYF-type pegmatites. This fractionation was enhanced by the presence of phosphorus and fluorine. Moreover, this study documented the importance of the prolonged fractionation magma that was produced as a result of the motion of the regional strike-slip fault in the origin of the NYF-type pegmatites in the within-plate setting.

\section{Acknowledgements}

I would like to thank all colleagues who assisted me in preparing this research, in Canada (Department of Earth and Planetary sciences, McGill University) and in Egypt (Nuclear Materials Authority).

\section{References}

Abd El-Naby H H and Frisch W 2006 Geochemical constraints from the Hafafit Metamorphic Complex (HMC): Evidence of Neoproterozoic back-arc basin development in the central Eastern Desert of Egypt; J. Afr. Earth Sci. 45 173-186.

Abdelsalam M G and Stern R J 1996 Sutures and shear zones in the Arabian Nubian shield; J. Afr. Earth Sci. 31 $289-310$

Abu Elatta S A 2018 The rare metal deposits of the El Garra Hamra syenites, South Western Desert, Egypt; Ore Geol. Rev. 101 609-628.

Abu Elatta S A, Assran H M and Ahmed A A 2013 Preliminary study on HFSE mineralization in the peralkaline granites of Nusab El Balgum Area, South Western Desert, Egypt; Geomaterials 3 90-101.

Ali M A, Lentz D I and Hall D C 2011 Mineralogy and geochemistry of Nb-, Ta-, Sn-, U-, Th-, and Zr-bearing granitic rocks from Abu Rusheid Shear Zones, South Eastern Desert, Egypt; Chin. J. Geochem. 30 226-247.

Attawiya M Y, Zalata A A, Ibrahim M E, Mostafa M E and Dawood N A 2000 Geology, geochemistry, and mineralogy of uraniferous pegmatites at Gabal Abu Dob, central Eastern Desert, Egypt; In: Fifth Arab conference on the peaceful uses of Atomic Energy, Beirut, pp. 26-45.

Bagiński B, Jokubauskas P, Domanska J, Kartashow P and Macdonald R 2016 Hydrothermal metasomatism of a peralkaline granite pegmatite, Khaldzan Buragtag massif, Mongolian Altai; complex evolution of REE-Nb minerals; Acta Geol. Pol. 66(3) 473-491.

Baker D R and Vaillancourt J 1995 The low viscosities of F $+\mathrm{H}_{2} \mathrm{O}$-bearing granitic melts and implications for melt extraction and transport; Earth Planet. Sci. Lett. 132 199-211.

Bau M 1996 Controls on the fractionation of isovalent trace elements in magmatic and aqueous systems; evidence from Y/Ho, Zr/Hf, and lanthanide tetrad effect; Contrib. Mineral. Petrol. 123 323-333.

Bau M and Dulski P 1999 Comparing yttrium and rare earth in hydrothermal fluids from the Mid-Atlantic Ridge: Implications for $\mathrm{Y}$ and REE behavior during near-vent mixing and for the $\mathrm{Y} /$ Ho ratio of Proterozoic Sea water; Chem. Geol. 155 77-90.

Beus A A 1982 Metallogeny of Precambrian rare-metal granitoids; Rev. Braz. Geos. 12 410-413.

Black R, Lameyre J and Bonin B 1985 The structural setting of alkaline complexes; J. Afr. Earth Sci. 3 5-16.

Blasband B, White S, Brooijmans P, De Boorder $\mathrm{H}$ and Visser W 2000 The Late Proterozoic extensional collapse in the Arabian-Nubian shield; J. Geol. Soc., London 157 615-628.

Boynton W V 1984 Geochemistry of the rare earth elements: Meteorite studies; In: Rare Earth Element Geochemistry (ed.) Henderson P, Elsevier, pp. 63-114.

Černý P 1991 Rare-element granitic pegmatites. Part 1: Anatomy and internal evolution of pegmatite deposits. Part 2: Regional to global environments and petrogenesis; Geosci. Can. 18 49-81.

Černý P and Ercit T S 2005 The classification of granitic pegmatites revisited; Can. Mineral. 43 2005-2026.

Collins W J, Beams S D, White A J R and Chappell B 1982 Nature and origin of A-type granites with particular reference to Southeastern Australia; Contrib. Mineral. Petrol. 80 189-200.

Dingwell D B, Hess K U and Knoche R 1996 Granite and granitic pegmatite melt: Volumes and viscosities; Trans. Roy. Soc. Edinburgh, J. Earth Sci. 87 65-72.

Eby G N 1990 The A-type granitoids. A review of their occurrence and chemical characteristics and speculations on their petrogenesis; Lithos 26 115-134.

Eby G N 1992 Chemical subdivision of the A-type granitoids: Petrogenetic and tectonic implications; Geology 20 641-644.

El-Ramly M F and Hussein A A 1982 The Alkaline Ring Complexes of Egypt; Geological Survey of Egypt, Paper No. $63,16 \mathrm{p}$. 
El-Ramly M F, Greiling R, Kroner A and Rashwan A A 1984 On the tectonic evolution of the Wadi Hafafit area and environs, Eastern Desert of Egypt; Faculty of Earth Science, King Abdulaziz University Bulletin 6 113-126.

El-Ramly M F, Greiling R, Rashwan A A and Rasmy A H 1993 Explanatory Note to Accompany the Geological and Structural Maps of Wadi Hafafit Area, Eastern Desert of Egypt; Geological Survey of Egypt, Paper No. 68.

El-Sayed M M 2003 The Neoproterozoic Dubr intrusives, Central Eastern Desert, Egypt: Petrological and geochemical constraints on the evolution of a mafic-felsic suite; Mineral. Geochem. 179 1-42.

El Sayed A M, Assran H M and Abu Elatta S A 2014 Petrographic, radiometric and paleomagnetic studies for some alkaline rocks, South Musab El Balgum Mass Complex, South Western Desert, Egypt; Geomaterials 4 $27-46$.

Erlank A J, Smith H S, Marchant J W, Cardoso M P and Ahrens L H 1978 Hafnium; In: Handbook of geochemistry (ed.) Wedepohl K H, Springer-Verlag, Berlin, Heidelberg, New York, pp. 72C1-72O1.

Fritz H, Dallmeyer R D, Wallbrecher E, Loizenbauer J, Hoinkes G, Neumayr P and Khudeir A A 2002 Neoproterozoic tectonothermal evolution of the central Eastern Desert of Egypt: A slow velocity tectonic process of core complex exhumation; J. Afr. Earth Sci. 34 137-155.

Garson M S and Kris M 1976 Geophysical and geological evidence of the relationship of Red Sea transverse tectonics to ancient fractures; Geol. Soc. Am. Bull. 87 169-181.

Green T H and Pearson N J 1986 An experimental study of $\mathrm{Nb}$ and $\mathrm{Ta}$ partitioning between Ti-rich minerals and silicate fluids at high temperature and pressure; Geochim. Cosmochim. Acta 51 103-111.

Grothaus B D, Eppler D and Ehrlich R 1979 Depositional environment and structural implications of the Hammamat Formation, Egypt; Ann. Geol. Surv. Egypt 9 564-590.

Harris N B W, Pearce J A and Tindle A G 1986 Geochemical characteristics of collision-zone magmatism; In: Collision Tectonics (eds) Coward M P and Ries A C, J. Geol. Soc. London, Spec. Publ. 19 67-81.

Hashad A H and El Reedy M W M 1979 Geochronology of anorogenic alkalic rocks. Southeastern Desert, Egypt; Ann. Geol. Surv. Egypt 9 81-101.

Hassan M A and Hashad A H 1990 Precambrian of Egypt; In: The Geology of Egypt (ed.) Said R, A. A. Balkema Rotterdam, Netherlands, pp. 201-245.

Henderson P 1982 Inorganic Geochemistry; Pergamon, Oxford, $312 p$.

Kogarko L N, Williams C T and Woolley A R 2002 Chemical evolution and petrogenetic implications of loparite in the layered, agpaitic Lovozero complex, Kola Peninsula, Russia; Mineral. Petrol. 74 1-24.

Kroner A, Kruger J and Rashwan A A 1994 Age and tectonic setting of granitoid gneisses in the Eastern Desert of Egypt and south-west Sinai; Geol. Rundsch. 83 502-513.

Lameyre J, Black R, Bonin B and Giret A 1984 Les provinces mamatiques de l'Est American, de I'Quest African et des Kerguelen. Indications d'un controle tectonique et d'une initiagtion superficielle du magmatism intraplaque et des processus associes; Ann. Soc. Géol. d'Nord C3(45) 101114.
Linnen R L 1998 The solubility of Nb-Ta-Zr-Hf-W in granitic melts with $\mathrm{Li}$ and Li-F: Constraints for mineralization in rare-metal granites and pegmatites; Econ. Geol. 93 1013-1025.

Loizenbauer L, Wallbrecher E, Fritz H, Neumayr P, Khudeir A A and Kloetzli U 2001 Structural geology, single zircon ages and fluid inclusion studies of the Meatiq metamorphic core complex: Implications for neoproterozoic tectonics in the Eastern Desert of Egypt; Precamb. Res. $110357-383$.

London D 1997 Estimating abundances of volatile and other mobile components in evolved silicic melts through mineral-melt equilibria; J. Petrol. 38 16911706 .

London D 2008 The Canadian Mineralogist; Spec. Publ., Vol. 10, $347 \mathrm{p}$.

London D 2009 The origin of primary textures in granitic pegmatites; Can. Mineral. 47 697-724.

Martin R F and De Vito C 2005 The patterns of enrichment in felsic pegmatites ultimately depend on the tectonic setting; Can. Mineral. 43 2027-2048.

Mbowou G I B, Lagmet C, Nomade S, Ngounouno I, Deruelle B and Ohnenstetter D 2012 Petrology of the late cretaceous peralkaline rhyolites (pantellerite and comendite) from Lake Chad, Central Africa; J. Geosci. 57 127141.

McDonough W F and Sun S S 1995 The composition of the earth; Chem. Geol. 120 223-253.

Migdisov A A and Williams-Jones A E 2002 A spectrophotometric study of neodymium (III) complexation in chloride solutions; Geochim. Cosmochim. Acta 66 43114323 .

Migdisov A A and Williams-Jones A E 2007 An experimental study of the solubility and speciation of neodymium (III) fluoride in F-bearing aqueous solutions; Geochim. Cosmochim. Acta 71 3056-3069.

Migdisov A A, Williams-Jones A E and Wagner T 2009 An experimental study of the solubility and speciation of the rare earth elements (III) in fluorideand chloride-bearing aqueous solutions at temperatures up to 300 degrees C; Geochim. Cosmochim. Acta $\mathbf{7 3}$ 7087-7109.

Moghazi A M, Hassanein M A, Mohamed F H and Ali S 2004 Late neoproterozoic strongly peraluminous leucogranites, south Eastern Desert, Egypt-petrogenesis and geodynamic significance; Mineral. Petrol. $\mathbf{8 1}$ $19-41$.

Omar S A 1995 Geology and geochemical features of the radioactive occurrences of Um-Anab granitic masses, Eastern Desert, Egypt; MSc Thesis, Cairo University, $195 \mathrm{p}$

Raslan M F 2008 The occurrence of ishikawaite (uraniumrich samarskite) in the mineralized Abu Rashied Gneiss, Southeastern Desert of Egypt; Int. Geol. Rev. 50(12) 1132-1140.

Rice A H N, Sadek M F and Rashwan A A 1993 Igneous and structural relations in the Pan-African Hammamat Group, Igla Basin, Egypt. Geoscientific research in Northeast Africa; In: Proceedings of the international conference on geoscientific research in Northeast Africa (eds) Thorwcihe U and Schan-delmeier H, Balkema, Rotterdam, pp. 35-39. 
Ries A C, Shackelton R M, Graham R H and Fitches W R 1983 Pan-African structures, ophiolites, and melange in the Eastern Desert of Egypt: A traverse at 26N; J. Geol. Soc. London 140 75-95.

Sabet T H and Tsogoev V B 1973 Problems of geological and economic evaluation of tantalum deposits in apogranites during stages of prospection and exploration; Ann. Geol. Surv. Egypt 3 87-107.

Saleh G M, Doaa A M, Darwish M and Salem I A 2014 Gabal El Faliq Granitoid rocks of the Southeastern Desert, Egypt: Geochemical constraints, mineralization and spectrometric prospecting; Standard Global J. Geol. Expl. Res. 1(1) 9-26.

Salvi S and Williams-Jones A E 2004 Alkaline granitesyenite deposits; In: Rare-element geochemistry and mineral deposits (eds) Linnen R L and Samson I M, Geol. Assoc. Can. Short Course Notes 17 315-341.

Scarrow J H, Bea F, Montero P and Molina J F 2009 Shoshonites, vaugnerites, and potassic lamprophyres: Similarities and differences between 'ultra' high-K rocks. Earth and environmental science; Trans. Roy. Soc. Edinburgh 99 159-175.

Serencits C M C, Faul H, Foland K A, El-Ramly M C and Hussein A A 1979 Alkaline ring complexes in Egypt: Their ages and relationship to tectonic development of the Red Sea; Ann. Geol. Surv. Egypt 9 102-116.

Stern R J and Hedge C E 1985 Geochronologic and isotopic constraints on late Precambrian crustal evolution in the Eastern Desert of Egypt; Am. J. Sci. 285 97-127.

Taylor S R and McClennan S M 1985 The continental crust: Its composition and evolution; Black well Scientific Publications, Oxford, UK, 312p.
Timofeev A, Migdisov A A and Williams-Jones A E 2017 An experimental study of the solubility and speciation of tantalum in fluoride-bearing aqueous solutions at elevated temperature; Geochim. Cosmochim. Acta 197 294-304.

Vail J R 1989 Ring complexes and related rocks in Africa; J. Afr. Earth Sci. 8 19-40.

Vincent E A and Nightingale G 1974 Gallium in rocks and minerals of the Skaergaard intrusion; Chem. Geol. 1463 73.

Wang R C, Fontan F and Monchoux P 1992 Minéraux disséminés comme indicateurs du caractère pegmatitique du granite de Beauvoir, massif d'Échassieres, Allier, France; Can. Miner. 30 763-770.

Wang X, Griffin W L and Chen J 2010 Hf contents and Zr/Hf ratios in granitic zircons; Geochem. J. 44 65-72.

Weyer S, Musker C, Rehkämper M and Mezger K 2002 Determination of ultra-low $\mathrm{Nb}, \mathrm{Ta}, \mathrm{Zr}$ and $\mathrm{Hf}$ concentrations and the chondritic $\mathrm{Zr} / \mathrm{Hf}$ and $\mathrm{Nb} / \mathrm{Ta}$ ratios by isotope dilution analyses with multiple collector CP-MS; Chem. Geol. 187 295-313.

Whalen J B, Currie K L and Chappell B W 1987 Atype granites: Geochemical characteristics, discrimination, and petrogenesis; Contrib. Mineral. Petrol. 95 407-419.

Willis K M, Stern R J and Clauer N 1988 Age and geochemistry of late Precambrian sediments of the Hammamat series from the Northeastern Desert of Egypt; Precamb. Res. 42 173-187.

Wolf M B and London D 1993 Preliminary results of HFS and RE element solubility experiments in granites as a function of B and P. EOS; Trans. Am. Geophys. Union 74(16) 343. 